San Jose State University

SJSU ScholarWorks

Master's Theses

Master's Theses and Graduate Research

Fall 2019

\title{
Relationship Between Habitat Variables and Leopard Shark (Triakis semifasciata) Population Trends in the South San Francisco Estuary
}

Patrice Frazier

San Jose State University

Follow this and additional works at: https://scholarworks.sjsu.edu/etd_theses

\section{Recommended Citation}

Frazier, Patrice, "Relationship Between Habitat Variables and Leopard Shark (Triakis semifasciata) Population Trends in the South San Francisco Estuary" (2019). Master's Theses. 5062.

DOI: https://doi.org/10.31979/etd.t5e5-75sh

https://scholarworks.sjsu.edu/etd_theses/5062

This Thesis is brought to you for free and open access by the Master's Theses and Graduate Research at SJSU ScholarWorks. It has been accepted for inclusion in Master's Theses by an authorized administrator of SJSU ScholarWorks. For more information, please contact scholarworks@sjsu.edu. 


\title{
RELATIONSHIP BETWEEN HABITAT VARIABLES AND LEOPARD SHARK (TRIAKIS SEMIFASCIATA) POPULATION TRENDS IN THE SOUTH SAN FRANCISCO ESTUARY
}

\author{
A Thesis \\ Presented to \\ The Faculty of the Department of Environmental Studies
}

San José State University

In Partial Fulfillment

of the Requirement for the Degree

Master of Science

by

Patrice June Frazier

December 2019 
(C) 2019

Patrice June Frazier

\section{ALL RIGHTS RESERVED}


The Designated Thesis Committee Approves the Thesis Titled

\title{
RELATIONSHIP BETWEEN HABITAT VARIABLES AND LEOPARD SHARK (TRIAKIS SEMIFASCIATA) POPULATION TRENDS IN THE SOUTH SAN
} FRANCISCO ESTUARY

\author{
by \\ Patrice June Frazier \\ APPROVED FOR THE DEPARTMENT OF ENVIRONMENTAL STUDIES \\ SAN JOSÉ STATE UNIVERSITY
}

December 2019

Lynne Trulio, Ph.D.

Kathryn Davis, Ph.D.

Rachel O’Malley, Ph.D.

Marilou Seiff, M.S.
Department of Environmental Studies

Department of Environmental Studies

Department of Environmental Studies

Executive Director, Marine Science Institute 


\section{ABSTRACT \\ RELATIONSHIP BETWEEN HABITAT VARIABLES AND LEOPARD SHARK (TRIAKIS SEMIFASCIATA) POPULATION TRENDS IN THE SOUTH SAN FRANCISCO ESTUARY}

by Patrice Frazier

The San Francisco Estuary (the Estuary) supports a diversity of native marine species, including the leopard shark (Triakis semifasciata). As the human population has increased in the Bay Area, elasmobranchs have simultaneously been subjected to habitat loss and changes in hydrology. On a large scale, global climate change is also affecting the Estuary's water quality. There is little research on the long-term population size of leopard sharks in the Estuary. Leopard shark catch data collected by the Marine Science Institute (MSI) and water quality data from the United States Geological Survey (USGS) from 1998 to 2017 were analyzed to assess long-term trends in leopard shark abundance, as well as the hydrological conditions in the southern portion of the Estuary that might be contributing to those trends. Results from this study indicated that the annual abundance of leopard sharks in this region has remained relatively stable over the study period despite interannual variability in CPUE and significant changes in fundamental abiotic estuarine elements. Low salinity was determined to influence leopard shark abundance when analyzed during the months of April to August. Further analyses on the status of leopard sharks as conditions related to climate change continue to challenge elasmobranch species could help managers protect the estuary environment. 


\section{ACKNOWLEDGMENTS}

I dedicate this work to the animals and plants that are consistently displaced and encroached on by humans. My hope is that this project will inspire positive change for future generations. The support, advice, and guidance I have received from many individuals throughout the years has given me the strength and confidence to complete this project. To my mother, Tanya, you have been my chief supporter. Your devotion, enthusiasm, positivity, and work ethic constantly inspire me to do my best while creating spaces for rejuvenation and personal health. To my husband Austin, you bring so much joy to my life - your accomplishments, humility, love, sincerity, energy, and the care that you put into each and every interaction constantly inspires me. You have taught me the importance of digging deep to build a complete story that does justice to the subject. To Tiff, Karen, Marilou, Captain Jackson, Captain Sean, and the entire Marine Science Institute staff between 2017 and 2019, your guidance, thoughtful curriculum, patience, and work ethic has made me physically and mentally stronger. I developed a deep understanding on the connectivity of all species within the San Francisco Estuary ecosystem and the responsibility humans have to continue promoting its wellbeing during my time with you all. To Dr. Trulio, Dr. Davis, and Dr. O'Malley, thank you for your guidance and advice. Your openness in permitting me to pursue a subject that was new to you is greatly appreciated. The knowledge each of you provided from your respective facets of biology made this a more wellrounded project, and integrated important concepts and techniques from each of your specialties. 


\section{TABLE OF CONTENTS}

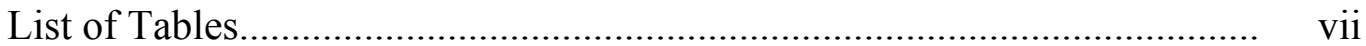

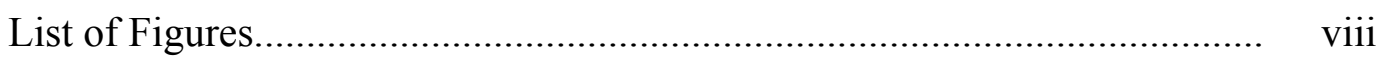

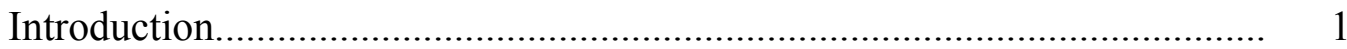

Literature Review...................................................................................... 5

Leopard Shark (Triakis semifasciata) Life History and Ecology....... 5

Population Status......................................................................... 7

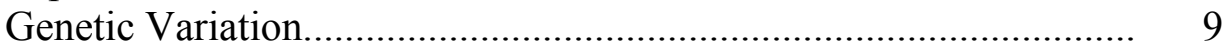

Size and Reproduction................................................................. 9

Abiotic Factors........................................................................... 11

Elasmobranch Die-offs................................................................. 11

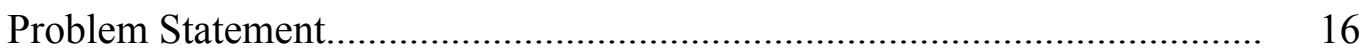

Research Question and Hypotheses........................................................... 17

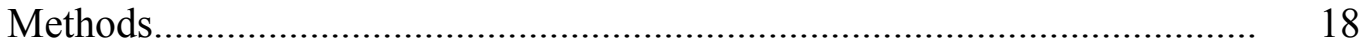

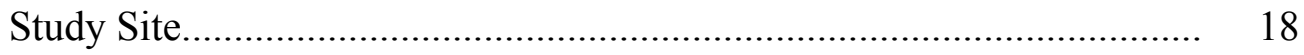

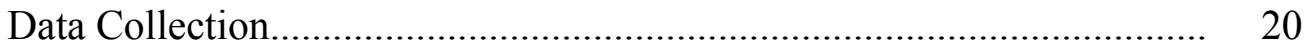

Data Analysis.................................................................................. 28

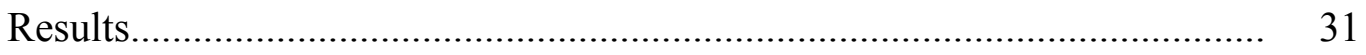

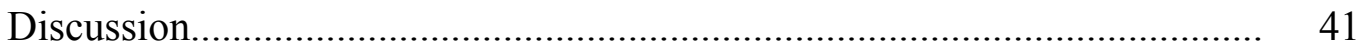

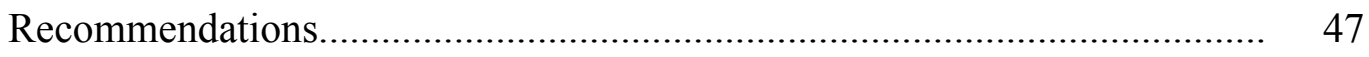

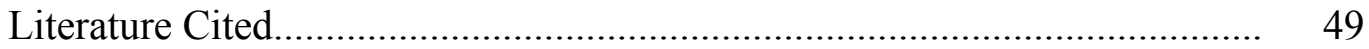

Appendix: Kruskal-Wallis H permutations for analysis of interannual variation in CPUE during the months of April to August from 1998 to 2017 


\section{LIST OF TABLES}

Table 1. Mean leopard shark CPUE values by month calculated using daily CPUE data from the Marine Science Institute's index from 1998 to 2017 


\section{LIST OF FIGURES}

Figure 1. Map showing the four divisions of the Estuary south of the Delta: Suisun Bay, San Pablo Bay, Central Bay, and the South

Bay

Figure 2. The Marine Science Institute's research vessel, the Robert G. Brownlee, which was the primary means for data collection, heading east on Redwood Creek

Figure 3. The otter trawl in tow off the stern of the Robert G. Brownlee......

Figure 4. Photo of the holding tanks onboard the Robert G. Brownlee filled continuously with water from the Estuary, which holds captured marine species.

Figure 5. A leopard shark being measured in the port side holding tank of the Robert G. Brownlee by two Marine Science Institute instructors.

Figure 6. United States Geological Survey water quality sampling stations in the Estuary.

Figure 7. National Oceanic and Atmospheric Administration climatology sampling locations indicated by pushpins

Figure 8. Scatterplot showing daily CPUE of leopard sharks captured between 1998 and 2017 by the Marine Science Institute...

Figure 9. Leopard shark mean CPUE values evaluated by month from 1998 to 2017 .......

Figure 10. April to August leopard shark CPUE results from Kruskal-Wallis test on variation between years

Figure 11. Scatterplot showing results from a regression test, which analyzed annual mean leopard shark CPUE from 1998 to 2017 using data from the months of April to August.

Figure 12. Annual salinity averages for the months of April to August from 1998 to 2017 obtained from USGS station 30 in the SFE. 
Figure 13. Annual (April to August) water temperature averages from 1998 to 2017 obtained from USGS sample station 30 in the

SFE.

Figure 14. Scatterplot illustrating the trend in leopard shark CPUE (squares) and salinity (circles) using data from the months of April to August between 1998 and 2017.

Figure 15. A map showing individual leopard sharks captured in the SFE by the Marine Science Institute between April and August of 2017 


\section{Introduction}

The San Francisco Bay Estuary (the Estuary) is a biologically diverse ecosystem that supports over 700 different marine species (Cohen, 2001; Mooi et al., 2007). Estuarine habitats receive water and sediment from both the ocean and adjacent rivers, which provide an abundance of nutrients to both resident and seasonal flora and fauna. This mixing of resources from neighboring waterways makes estuarine environments extremely productive and biodiverse.

As the largest estuary ecosystem in the western portion of the Americas, the Estuary greatly contributes to the ecological diversity of the region (Mooi et al., 2007). As with most regions on the planet with an abundance of natural resources, the San Francisco Bay area has attracted a sizable human population (Paddison, 2005). Within a span of 250 years, the human population in the Bay Area has expanded from approximately 500,000 individuals to over 7 million (Mooi et al., 2007; Paddison, 2005). Intensive resource extraction practices that began in the $17^{\text {th }}$ century have permanently altered the ecology of the Estuary in a relatively short time period (Mooi et al., 2007; The Bay Institute of San Francisco, 1998).

Anthropogenic activities have long had an impact on the health of estuary ecosystems globally (Brar, Waggoner, Reyes, Fairey \& Kelley, 2009; Davis, Hetzel, Oram \& McKee, 2007). Physical habitat alterations and extreme environmental phenomena due to global climate change have changed the Estuary's water composition and nutrient availability, which has in turn impacted its biota (The Bay Institute of San Francisco, 1998). Since the 1800s, the Estuary has suffered major anthropogenic impacts such as extreme 
sedimentation as a result of hydraulic mining from the Gold Rush, loss of approximately $85 \%$ of historic tidal wetlands to filling and diking, and the installation of dams, reservoirs, and canals which divert fresh water away from the Estuary (Cook, 2012; Mooi et al., 2007; The Bay Institute of San Francisco, 1998). Point source pollution has introduced effluent and chemicals such as polychlorinated biphenyls, pharmaceuticals and a range of pesticides, as well as heavy metals such as lead and mercury into the Estuary's mudflats and waters (Davis et al., 2002; Klosterhaus, Yee, Sedlak, Wong \& Sutton, 2013; Mooi et al., 2007; Russo, 1975). Non-point source pollution has impacted the Estuary in the form of urban runoff from increased urban development (Thompson et al., 2007), mercury runoff from closed cinnabar mines, and agricultural runoff from neighboring farmland (Rabalais, Turner, Diaz \& Justic, 2009). In addition, the five-year prolonged California drought from 2012 to 2016 (United States Geological Survey, 2018), competition from introduced non-native species, and over-fishing have resulted in the threatened or endangered status of many key native species in the San Francisco Bay (The Bay Institute of San Francisco, 1998). Species such as the coho Salmon (Oncorhynchus kisutch), rainbow trout (Oncorhynchus mykiss), delta smelt (Hypomesus transpacificus), and white sturgeon (Acipenser transmontanus), are native inhabitants of the Estuary and Delta region whose populations have declined drastically as the human population has increased (The Bay Institute of San Francisco, 1998).

One key native and resident marine species of the San Francisco Bay is the leopard shark, which has recovered in recent years from overexploitation. Elasmobranch species, such as the leopard shark, are essential to marine ecosystems (Ackerman, 1971; Myers, 
Baum, Shepherd, Powers \& Peterson, 2007; Stevens, Bonfil, Dulvy \& Walker, 2000; Webber \& Cech, 1998), as they are a native predator which assists in maintaining the overall health of marine ecosystems (Bascompte, Melian \& Sala, 2005; Kao, 2000; Russo, 1975; Talent, 1976). Without regulation from a top predator, lower trophic level organisms, such as benthic invertebrates and fish populations, can reach levels that can decimate an ecosystem through tropic cascades (Bornatowski, Navia, Braga, Abilhoa \& Correa, 2014; Myers et al., 2007; Navia et al., 2012; Stevens et al., 2000).

Populations of leopard sharks, and other elasmobranchs that regularly converge in the Estuary have experienced periodic die-off events. Starting in 1956, there have been reports of stranded, struggling, or dead leopard sharks and other elasmobranch species found on the shores throughout the Estuary. Retallack et al. (2018) identified the fish parasite, Miamiensis avidus (M. avidus), as the most likely cause of the recent elasmobranch die-off. An infection from M. avidus in fish results in disorientation and death as the parasite eats away at the brain tissue of its host (Harikrishnan et al., 2012). A more comprehensive understanding as to why elasmobranchs in the Estuary are particularly susceptible to this parasite is needed.

Elasmobranch die-offs are concerning, especially when considering their status as a food web regulating predator. There has been little assessment of the long-term population status of leopard sharks in the Estuary, nor have the factors that might contribute to their population status been studied. Hobbs, Cook and Crain (2015) recently conducted a four-year study in the South San Francisco Estuary (SFE) and found that the abundance of leopard sharks is dependent on abiotic factors such as salinity and dissolved 
oxygen, as well as habitat preference. Leopard sharks were more common in tidal sloughs and restored tidal ponds (Hobbs et al., 2015). However, this was a very shortterm study that focused on conditions in ponds undergoing restoration. An understanding of long-term leopard shark population changes and associated factors, especially in the face of climate change, could help managers understand the trajectory of this species in the Estuary for management and conservation.

This research examined a long-term data set in the SFE that provided an index of the leopard shark population over time with the goal of providing information to policy makers, conservation groups, and the general public on the status of leopard sharks. This research investigated habitat variables that could impact leopard sharks in this region as global climate change continues to alter estuarine ecosystems at an increasingly rapid pace. Decision makers in regions where leopard sharks are present can use the results of this study to determine how to best protect elasmobranch species in the long term. This research project will contribute to the growing field of marine exploration, helping humans to better understand and be positively curious about the many wonders of marine ecosystems, as well encourage awareness of the repercussions already evident if the continued mistreatment of the planet's waterways continues. 


\section{Literature Review}

\section{Leopard Shark (Triakis semifasciata) Life History and Ecology}

Leopard sharks are marine vertebrates that belong to a class of fishes referred to as Chondrichthyes, which are cartilaginous fish (Castro, 1983; Wilga, Motta \& Sanford, 2007). They are further divided into a subclass of Chondrichthyes known as elasmobranchs (Barker, Nosal, Lewallen \& Burton, 2015; Castro, 1983; Wilga et al., 2007). Leopard sharks share this subclassification with rays, skates, and a variety of other shark species (Castro, 2011; Ebert, 1986; Wilga et al., 2007). Leopard sharks are one of eleven species of elasmobranchs that inhabit the Estuary and utilize it year-round (Self, 2010).

Leopard sharks are endemic to the Pacific coast along the western portion of the United States (Castro, 2011). They range from as far south as the Gulf of California, to Oregon, USA (Ackerman, 1971; Castro, 1983; Castro, 2011; Ebert, 2003; Smith and Abramson, 1990), although a male leopard shark was reported in Samish Bay off the coast of Washington, USA (Barker et al., 2015; Farrer, 2009). Leopard sharks are commonly found in cool shallow water, at a depth between 12 to 24 feet from April and October (Castro, 1983).

Leopard sharks are schooling sharks that tend to congregate in a range of benthic habitats along the Pacific west coast including: bays, estuaries, sandy beaches, kelp forests, and sheltered coves (Ackerman, 1971; Castro, 1983; Russo, 1975; Smith, 2001). Recent work has revealed that they can also be found aggregating in open coastal waters, particularly in Southern California (Nosal et al., 2013). One factor that remains constant 
in leopard shark habitat preference is temperature, as it is one of the leading abiotic factors that influences their distribution (Castro, 1983; Hopkins \& Cech, 2003). Additional abiotic factors that influence leopard shark distribution are salinity, shelter from larger predators, and the concentration of dissolved oxygen (Desmond, Deutschman \& Zedler, 2002; Ebert, 1986; Fish, Messineo \& Hieb, 2011; Hight \& Lowe, 2007; Hopkins \& Cech, 2003; Mejia, Saiki \& Takekawa, 2008; Miklos, Katzman \& Cech, 2003). Leopard shark habitats also tend to be nutrient-rich, which tends to promote a plentiful variety of food for sustenance (Carlisle, King, Cailliet \& Brennan, 2007; Hight \& Lowe, 2007). Leopard sharks are a benthic-foraging shark species that spend most of their time on or near the bottom of the water column (Barker et al., 2015; Castro, 1983; Russo, 1975). They are resourceful consumers that feed on variety of organisms depending on seasonality, size, and availability (Ackerman, 1971; Castro, 1983). Two independent stomach content analyses conducted by Russo (1975) and Kao (2000) revealed the most common food items frequently consumed by leopard sharks, which include: shrimp, crabs, fish (perch, anchovy, goby, sanddab), fish eggs (herring, smelt, plainfin midshipman), clam necks, worms (bristle worms and fat innkeeper worms), squid, eelgrass, and octopus. The amount and type of food varies in leopard shark populations depending on shark size, location, and prey availability (Ackerman, 1971; Kao, 2000).

Leopard sharks are one of the most abundant elasmobranch species found within the Estuary (Ebert, 2003). Smith and Abramson (1990) conducted a 9-year study on the distribution of leopard sharks throughout the Estuary. Their results revealed that out of 
101 individuals, $88 \%$ were recaptured within the confines of the Estuary, and 59\% were recaptured in the SFE within the 9-year time span. In winter months, they disperse to deeper water or shallow regions within the Estuary as temperatures drop and salinity decreases (Hopkins \& Cech, 2003; Talent, 1985). The Estuary provides first and secondary nursery habitat, food, shelter and protection from predators making it an integral habitat in the life history of this species (Russo, 2015; Russo, 2019).

\section{Population Status}

Elasmobranchs have adapted and thrived in coastal estuary environments over the course of 320 million years (Lund, 1990). Past research reveals that anthropogenic alterations to coastal estuaries, such as the Estuary, have transformed the ecosystem at a more rapid pace than many marine organisms can adapt, resulting in population declines due to anthropogenic contaminant exposure, overfishing, and coastal development (Davis et al., 2002; Ebert, 1986; Hight \& Lowe 2007; Hopkins \& Cech, 2003; Miklos et al., 2003; Stewart, Luoma, Schlekat, Doblin \& Hieb, 2004).

Reported catch counts from annual shark derbies held from the 1940s to the 1990s in Elkhorn Slough, California and in the Estuary provided evaluations of the relative population status of leopard sharks in these regions during this time period (Carlisle et al., 2007; Herald, 1953; Herald \& Ripley, 1951). Herald and Ripley (1951) utilized catch records from the annual Coyote Point shark derbies and California Fish and Game to assess the population status of leopard sharks in the central and southern portions of the Estuary. Their findings indicated a sporadic presence of leopard sharks depending on the year. Leopard sharks were 13 percent of the catch in 1943, 46.3 percent of the catch in 
1948, and 28.2 percent in 1950 (Herald \& Ripley, 1951). Later, Smith and Abramson (1990) conducted a geographic distribution and stock replenishment assessment on leopard sharks in the Estuary from 1979-1988. They concluded that the population is largely residential with less that 10 percent venturing out the Estuary during fall and winter months, and that management of the species should involve a $100 \mathrm{~cm}$ size limit for fishing (Smith \& Abramson, 1990).

In Elkhorn Slough, the average overall catch and abundance of elasmobranchs declined from the 1980s to 1990 s, most likely due to habitat alterations such as erosion, which results in decreased access to benthic organisms, a main food source (Carlisle et al., 2007; Kao, 2000; Russo, 1975; Talent, 1976). A 2011 leopard shark status and trends population study conducted in the Estuary showed a decline in the number of individuals since 1984 (Fish et al., 2011).

As of 2006, recreational and commercial catch statistics indicate that management policies have maintained the leopard shark population (Smith \& Horeczko, 2008). While leopard shark populations are not considered threatened, according to the International Union for Conservation of Nature and Natural Resources (IUCN) Red List of Threatened Species, their continued popularity as a sport fish, slow growth rate, late age of sexual maturity, and low reproduction rate are potential vulnerabilities to the stability of the leopard shark population (Barker et al., 2015; Carlisle et al., 2007; Smith \& Abramson, 1990). Although a three-animal bag limit and 36 inch $(91.44 \mathrm{~cm})$ total length $(\mathrm{TL})$ size limit was been implemented in 1992 (California Department of Fish and Wildlife, 2019; 
Smith \& Horeczko, 2008), consistent monitoring of the population and proper stock assessments are needed to prevent overexploitation of the fishery.

\section{Genetic Variation}

Genetic variation within a species is an essential component of its survival. Genetic variation is responsible for the characteristics that make an individual species unique, but most importantly as it relates to this study, genetic variation can explain why some individuals or populations are more susceptible than others to biological threats (Barker et al., 2015; Lewallen \& Anderson, 2007). Research on the genetic connectivity between different leopard shark populations along the Pacific west coast revealed that while leopard sharks do tend to practice natal philopatry, some subpopulations of leopard sharks are genetically distinct from one another, which hints that both stationary and migratory leopard shark populations exists (Barker et al., 2015; Lewallen \& Anderson, 2007; Smith \& Abramson, 1990). Barker et al. (2015) argue that genetic isolation from other leopard shark populations leaves the isolated population susceptible to decline due to a lack in genetic variation.

In addition, Lewallen and Anderson (2007) revealed that leopard sharks innately have little genetic variation, most likely due to the slow development rate of their mitochondrial DNA (mtDNA). Through the process of reproduction, more favorable characteristics are passed on to offspring, resulting in an overall more genetically tough individual with the ability to adapt to an ever-changing environment.

\section{Size and Reproduction}


The maximum size of an individual was recorded at $198.1 \mathrm{~cm}(6.49 \mathrm{ft})$ total length (TL), although a leopard shark greater than $145.0 \mathrm{~cm}(4.76 \mathrm{ft})$ has not been recorded since Miller and Lea's published guide to Coastal Marine Fishes (Miller and Lea, 1972). Female leopard sharks grow larger than males over time (Castro, 1983; Kusher, Smith \& Cailliet, 1992). Female leopard sharks reach sexual maturity between 10 to 15 years of age (105 cm TL to $135 \mathrm{~cm} \mathrm{TL)} \mathrm{(Ackerman,} \mathrm{1971;} \mathrm{Kusher} \mathrm{et} \mathrm{al.,} \mathrm{1992),} \mathrm{with} \mathrm{a} \mathrm{gestation}$ period between 10 and 12 months (Ackerman, 1971; Kusher et al., 1992). Females produce between 7 to 36 pups, with an increase in the number of pups with age (Ackerman, 1971; Ebert \& Ebert, 2005). Males reach maturity between 7 and 13 years of age (100 cm TL to $105 \mathrm{~cm}$ TL) (Kusher et al., 1992).

Females are ovoviviparous, retaining their young throughout the entire gestation period (Ackerman, 1971; Smith \& Horeczko, 2008). At birth, juvenile leopard sharks are between $17 \mathrm{~cm}$ (6.69 in) and $20 \mathrm{~cm}$ (7.87 in) (Ackerman, 1971; Ebert \& Ebert, 2005; Kusher et al., 1992). Males have an average lifespan of at least 24 years, and reach an approximate length of $149.86 \mathrm{~cm}$ (59 in), while females live, on average, 20 years reaching an approximate length of $180.34 \mathrm{~cm}$ (71 in) (Smith \& Horeczko, 2007).

The popularity of leopard sharks as a sportfish, their low genetic variability, slow reproduction rate, and long gestation period makes them susceptible as a species to overexploitation (Ackerman, 1971; Barker et al., 2015). Further research is needed to assess the population status of less genetically diverse leopard shark populations, especially in potential resident populations where genetic variations are less frequent and therefore may pose a potential threat to the survival of that distinct subpopulation. 


\begin{abstract}
Abiotic Factors
Abiotic factors such as temperature, salinity, and dissolved oxygen play a major role in the survival of leopard sharks (Dowd, Harris, Cech \& Kultz, 2010; Hopkins \& Cech, 2003). Leopard sharks are ectothermic and therefore rely on temperature to maintain physiological internal processes such as metabolic processing and reproduction (Dowd et al., 2010; Hopkins \& Cech, 2003). Hopkins and Cech (2003) found that temperature and salinity levels determined the movement patterns of leopard shark populations in Tomales Bay and as salinity levels decreased, leopard sharks moved out of Tomales Bay into the open ocean.
\end{abstract}

Temperature also plays a role in the oxygen consumption of leopard sharks (Miklos et al., 2003). As their core temperature increased, leopard sharks were able to more efficiently metabolize their food, helping to explain why leopard sharks congregate near the shore during high tide as they forage for benthic invertebrates, usually during the warmest part of the day (Miklos et al., 2003).

Dowd et al. (2010) found that leopard sharks tend to congregate in areas of the ocean where salinity levels are above 18 parts per thousand (ppt). When salinity levels drop below 18 ppt conditions become more challenging for the sharks to survive and they are forced to compensate for the decline in salinity with a change in physiological and metabolic processes (Hopkins \& Cech, 2003).

\title{
Elasmobranch Die-offs
}

Multiple elasmobranch die-offs have been reported since 1967. In 1968, Russo and Herald (1968) published a review of a significant elasmobranch die-off that occurred 
between July and August 1967. More than 725 elasmobranchs were found dead or disoriented from the Alameda Beach Recreational Area to the shores of the Golden Gate Park in San Francisco (Russo \& Herald, 1968). Russo and Herald (1968) suggested that the mass elasmobranch die-off was caused by the release of a toxic contaminant, which caused a similar die-off of striped bass in the same region ten years earlier. In collaboration with the Environmental Protection Agency (EPA) in 1969, Russo collected five liver samples from two species of shark species native to the Estuary, leopard sharks and brown smoothhound sharks, to test for the presence of PCBs and chlorinated hydrocarbons. His findings revealed that leopard shark livers contained a significantly higher concentration of PCBs (46.9 ppm to $22.5 \mathrm{ppm}$ ) and chlorinated hydrocarbons (108.2 ppm to $36.9 \mathrm{ppm}$ ) compared to those of the brown smoothhound sharks. Although a threshold for contamination had not yet been established by the EPA (Russo, 1975), additional studies confirmed Russo's findings, prompting the introduction of policies aimed at reducing contaminants in the Estuary. While a 1957 striped bass die-off was caused by a leak of toxic contaminants that flowed into the Estuary from a nearby manufacturing plant, there was no conclusive evidence to suggest that the 1967 elasmobranch die-off was linked to toxic leakage (Herald \& Russo, 1968; Russo, 2015). Herald and Russo (1968) also discussed another possible source of toxic contamination that may have come from Naval aircraft carriers docked at the Alameda Naval Station, but no conclusive evidence could confirm or refute this hypothesis.

Between May and September 1982, eighty elasmobranchs, including twenty-nine leopard sharks, were found dead or dying on the coast of Alameda's Robert Crown 
Memorial State Beach (Russo, 2015). In the spring of 2006 multiple dead and dying elasmobranchs were found along the shores of the South and Central Bay following heavy spring rains (Simons, 2017a). From April to July 2011 leopard sharks and bat rays (Myliobatis californica) again were found dead or dying on the shores throughout the South and Central Bay, with some deceased leopard sharks found near tide gates following heavy spring rainfall after a dry winter (Fish et al., 2011; Simons, 2017b). The cause of the elasmobranch die-offs was routinely undetermined, but several hypotheses were suggested including salinity, temperature, dissolved oxygen levels, and contaminant concentrations.

The most recent recording of an elasmobranch die-off occurred in 2017 in the Estuary. Similar to previous die-offs in the region, dead and disoriented elasmobranchs were found along the shores from February to July (Simons, 2017b). An estimated 1,000 elasmobranch species fell victim to this most recent die-off (Simons, 2017a). Pathologist Mark Okihiro with the California Department of Fish and Wildlife extracted cerebral fluid from several dead sharks in the Estuary, which was then sent to the lab of Joseph DeRisi at the University of California, San Francisco where it was analyzed by Hanna Retallack and intern Elliot Britton (Retallack, Okihiro, Britton, Sommeran and DeRisi, 2018; Simons, 2017a). Retallack and Britton determined that the 2017 elasmobranch dieoff was most likely caused by a ciliate protozoan known as Miamiensis avidus (M. avidus), a fish parasite (Retallack et al., 2018; Simons, 2017a). Using a polymerase chain reaction (PCR) genetic sequencing technique, M. avidus DNA was found in all of the dead leopard sharks sampled (Retallack et al., 2018; Simons, 2017a). In addition, 
common symptoms such as disorientation, death, brain hemorrhaging, ulcers, and discoloration of surface tissue were all characteristics of infection by $M$. avidus (Harikrishnan et al., 2012; Jung, Shin-Ichi, Song \& Oh, 2007; Woo \& Buchmann, 2012).

Studies on farmed fish whose populations have been decimated by M. avidus in South Korea and Japan provide useful information on the infection process of this ciliate protozoan. Jung et al. (2007) focused on the process of infection of olive flounder when exposed to M. avidus under laboratory settings. This study also revealed that $M$. avidus enters the host through the skin and/or gills directly from seawater and spreads via blood throughout the organism. Once $M$. avidus has entered its host it consumes host cells and body fluids and then spreads to internal organs, such as the brain, as seen in infected elasmobranchs from the Estuary (Jung et al., 2007). Because M. avidus can enter its host via skin contact, flat fish such as olive flounder are more susceptible to rapid transmission of the infection because they spend a significant amount of their life stationary, stacked on top of each other at the bottom of the water column (Jung et al., 2007).

Leopards sharks, like olive flounder, tend to congregate in schools as opposed to leading isolated lives. In addition, the leopard shark population in the Estuary is likely a resident subpopulation that does not often stray far from the Bay Area (Barker et al., 2015; Lewallen \& Anderson, 2007; Smith, 2001). The parasite M. avidus has been linked to the most recent leopard shark die-off, but additional research is needed to confirm whether M. avidus is also responsible for previous elasmobranch die-off dating back to 1967. A more comprehensive understanding as to why, when, and how this fish parasite 
infects elasmobranchs is needed in order to implement management policies that can effectively prevent future die-offs. 


\section{Problem Statement}

Leopard sharks (Triakis semifasciata) play a significant role in the health of the Estuary ecosystem (Barker et al., 2015; Lewallen \& Anderson, 2007; Stewart et al., 2004). As a native predator, leopard sharks assist in maintaining the balance between predator and prey (Barker et al., 2015; Bascompte et al., 2005; Lewallen \& Anderson, 2007; Stewart et al., 2004). Fishing pressure, exposure to anthropogenic contaminants, urban development, and abiotic fluctuations due to climate change in the Estuary have the potential to threaten the population of leopard sharks, which can in turn result in an ecosystem imbalance (Cohen, 2001; Gunther et al., 2011; Russo, 1975; Stewart et al., 2004; Thompson et al., 2007).

There is little information on long-term population trends of leopard sharks in the Estuary. This study was designed to: (1) quantify the relative abundance of leopard sharks in the SFE 1998 to 2017; (2) evaluate salinity, precipitation, and water temperature in the SFE; and (3) assess the relationship between a number of estuarine abiotic factors and leopard shark relative abundance at the study site. I hypothesized that the relative abundance of leopard sharks had changed in response to abiotic conditions, especially water salinity and temperature, during the study period. I used these hypotheses and this research question to address these objectives: 


\section{Research Question and Hypotheses}

$\mathrm{H}_{0} 1$ : The relative abundance of leopard sharks has not changed over time as determined by the catch-per-unit-effort index.

$\mathrm{H}_{0} 2$ : The relative abundance of leopard sharks did not vary daily, monthly, or seasonally in the Estuary.

$\mathrm{H}_{0} 3$ : Abiotic conditions, including water salinity, water temperature, and precipitation has not changed over time.

$\mathrm{H}_{0} 4$ : There is no relationship between salinity and water temperature on leopard shark relative abundance during summer months in the Estuary.

Research Question 1. Does the pattern of major leopard shark die-offs seem to match the pattern of change in salinity? 


\section{Methods}

\section{Study Site}

Data for this study were collected in the Estuary, in the region below the San Mateo

Bridge (Figure 1). 


\section{Divisions of the San Francisco Estuary-Delta}

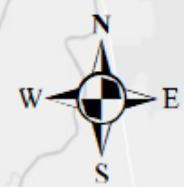

San Pablo

Bay

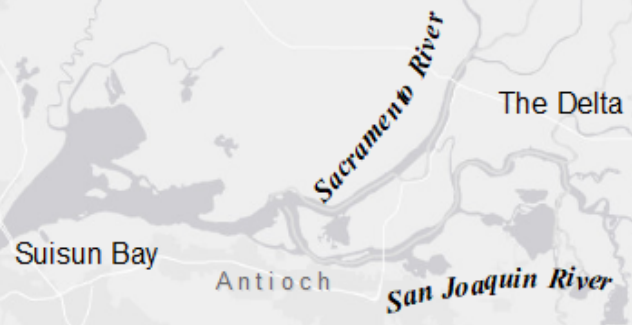

Central Bay

San Francisco

Pacific Ocean

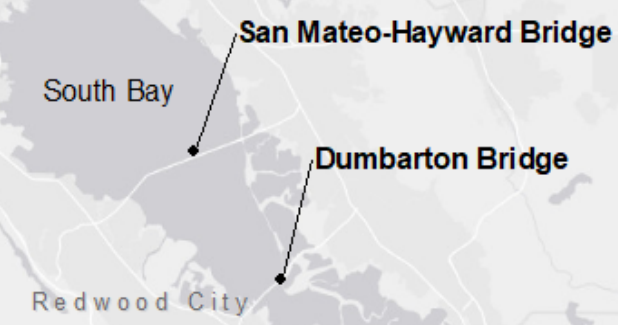

\section{Kilometers}

San Jose

$\lfloor\perp \perp \perp \perp$

Source: Map created using ArcGIS software by ESRI Map Prepared by: Patrice Ringelstein

Figure 1. Map showing the four divisions of the Estuary south of the Delta: Suisun Bay, San Pablo Bay, Central Bay, and the South Bay. 
Due to its geographic distance from primary sources of fresh water (from the Delta), the SFE is, on average, shallower, warmer, and has a higher salinity when compared to the central and northern sections of the Estuary (Cohen, 2001) (Figure 1). The water temperature in Redwood City, CA, which is located in the southern portion of the Estuary, ranges from $16^{\circ} \mathrm{C}-21^{\circ} \mathrm{C}$ (Cohen, 2001). Salinity ranges from 15 to 36 parts per thousand (ppt) (Cohen, 2001). The California Department of Fish and Game and the National Oceanic and Atmospheric Administration regulate the Estuary.

\section{Data Collection}

Catch-per-unit-effort (CPUE), to develop an index of relative abundance of leopard sharks in the Estuary from 1998 to 2017, was provided by the Marine Science Institute (MSI). Leopard sharks were collected by the Marine Science Institute's research vessel, the Robert G. Brownlee, a 90-foot research vessel designed for the conditions of the Estuary (Figure 2). The vessel was put into operation in 1998 with the sole purpose of operating as an educational research vessel. It can accommodate a maximum of 70 passengers. Leopard sharks were captured during educational programs titled Discovery Voyages and Eco Voyages. During Discovery Voyages and Eco Voyages, trained instructors guide students through a four-hour intensive marine science curriculum aboard the research vessel, in addition to collecting and recording species data. Discovery Voyages embark twice daily Monday to Friday between the hours of 8 AM and 5 PM. Eco Voyages embark on intermittent Saturdays between 9 AM and 12 PM. During the year of 2017, I was employed by the Marine Science Institute as an instructor and assisted in species data collection onboard the vessel. 


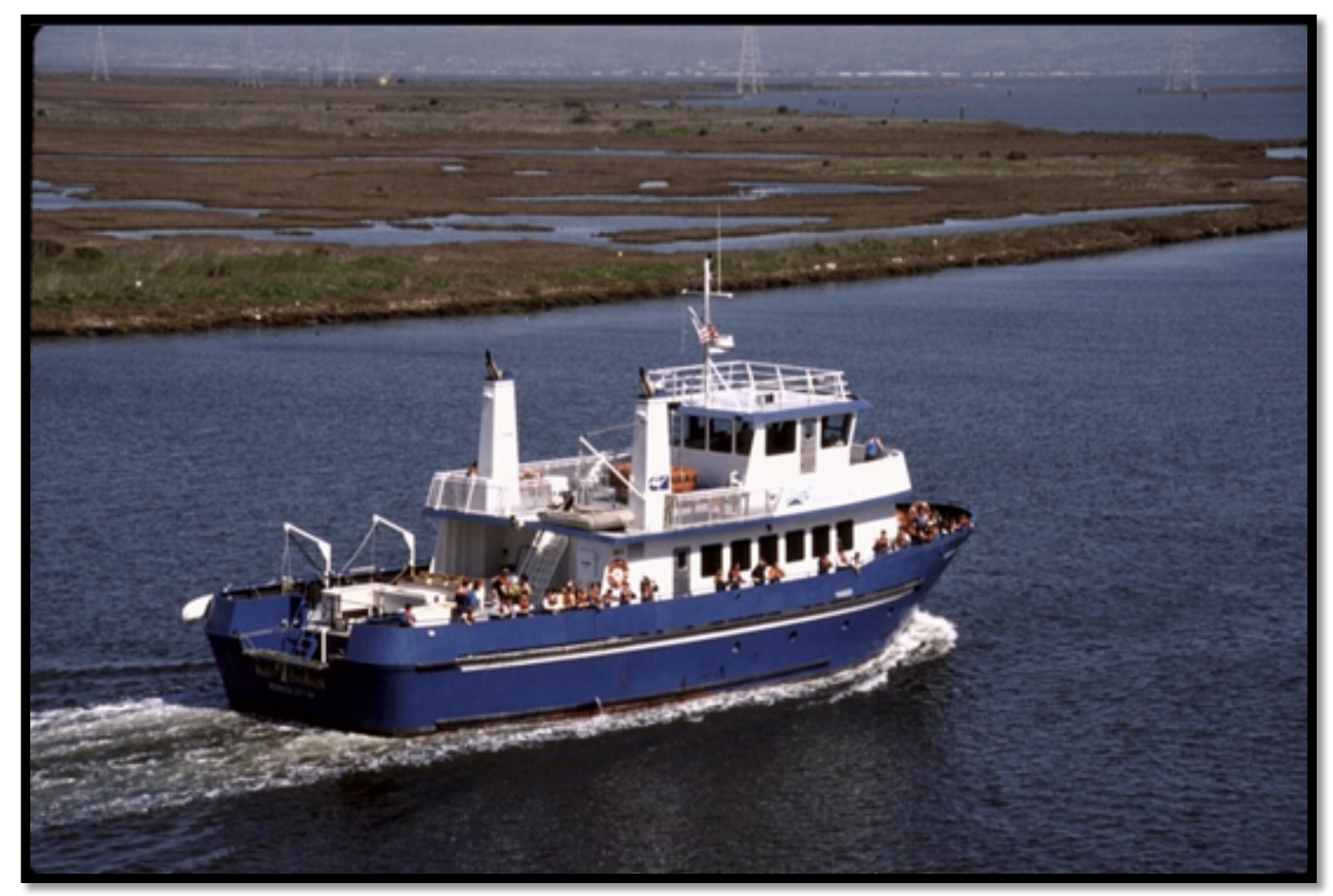

Figure 2. The Marine Science Institute's research vessel, the Robert G. Brownlee, which was the primary means for data collection, heading east on Redwood Creek. Reprinted with permission from the Marine Science Institute (Marine Science Institute, 2019).

Between 1998 and 2017, data collection occurred on the research vessel Robert G. Brownlee primarily between coordinates $37.5048^{\circ} \mathrm{N}, 122.1204^{\circ} \mathrm{W}$, the Dumbarton Bridge, and $37.5907^{\circ} \mathrm{N},-122.2429^{\circ} \mathrm{W}$, the San Mateo-Hayward Bridge. Data collection took place Monday through Friday, between 08:00 and 17:00. Leopard shark catch data analyzed for this study were collected from January to December.

The otter trawl used aboard the Marine Science Institute's vessel to capture marine species is equipped with two wooden otter boards, which are attached at the end of each 60-foot warp. The wooden otter board function to keep the net horizontally open. When trawling, the speed of the vessel was between 2 to 3 knots and was in tow for 5 to 12 
minutes depending on the length of the program. The slow speed and short trawl time were intended to reduce the occurrence of injuries to the animals and to prevent the trawl from dragging exclusively along the bottom (Captain Jackson, in correspondence).

The Captain recorded the start and end coordinates for each trawling session in degrees, decimal, minute (DDM). This study spatially analyzed catch data and trawling locations recorded during the months of April to August of 2017 for visual purposes. DDM coordinates were converted to decimal degrees (DD) before they could be input into ArcGIS. DDM coordinates were converted using Microsoft Excel.

Degrees (d) values were separated from the decimal and minutes (DM) values and placed into two separate columns, one column for degrees values and one column for the decimal and minute values. A period was then placed between the decimal and minute coordinates. A negative sign was placed before all longitude coordinates in compliance with the requirements defined by the WGS84 coordinate reference system used in ArcGIS. DD was calculated in a new column using the formula below:

$$
D D=d+(D M / 60)
$$

The trawl was submerged at the stern of the Brownlee between five to ten minutes before being drawn in. Once the otter trawl was pulled in, captured marine species were identified, measured to the nearest centimeter, and then released (Figure 3, 4 and 5). 


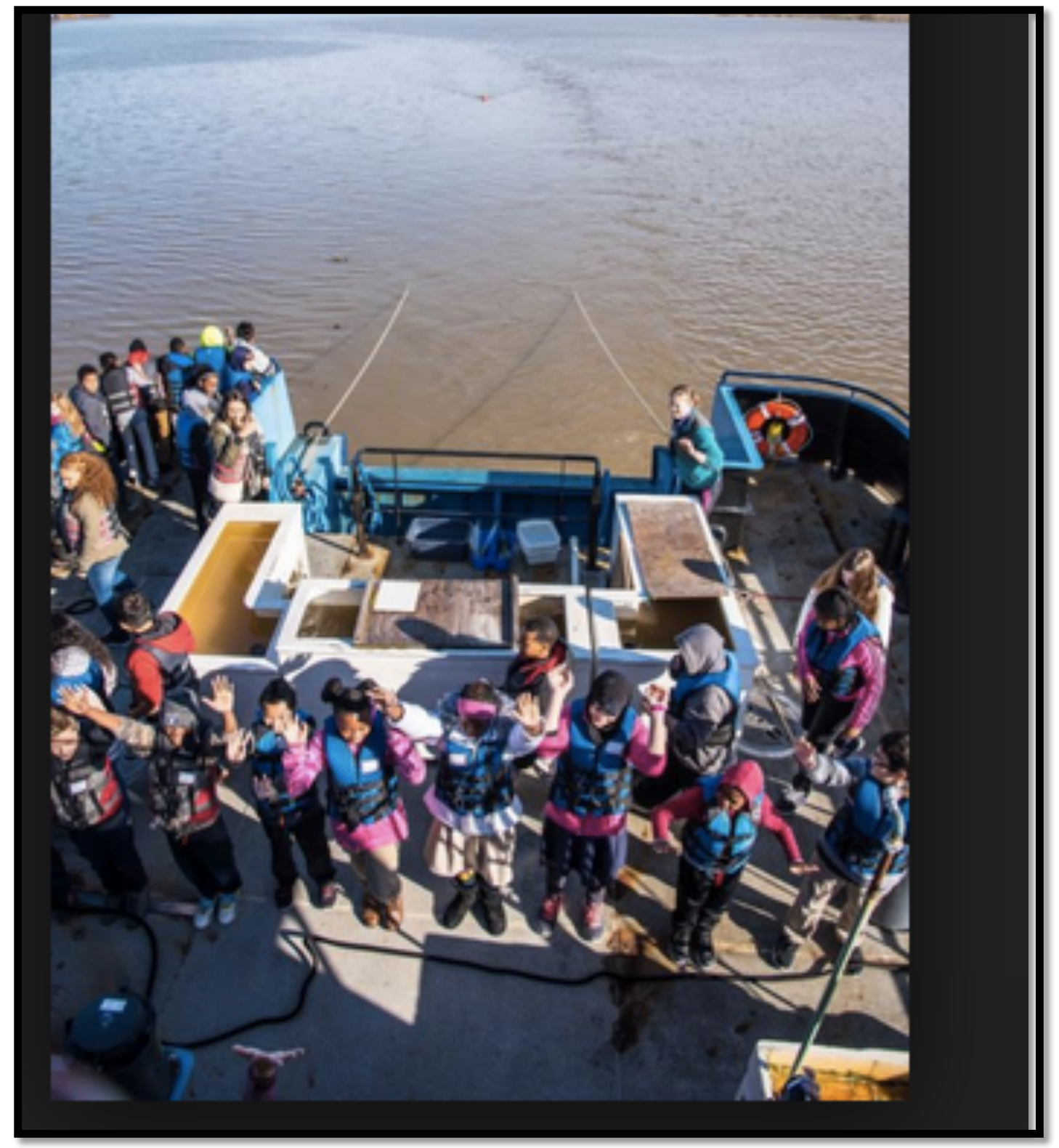

Figure 3. The otter trawl in tow off the stern of the Robert G. Brownlee. Reprinted with permission from the Marine Science Institute (Marine Science Institute, 2019). 


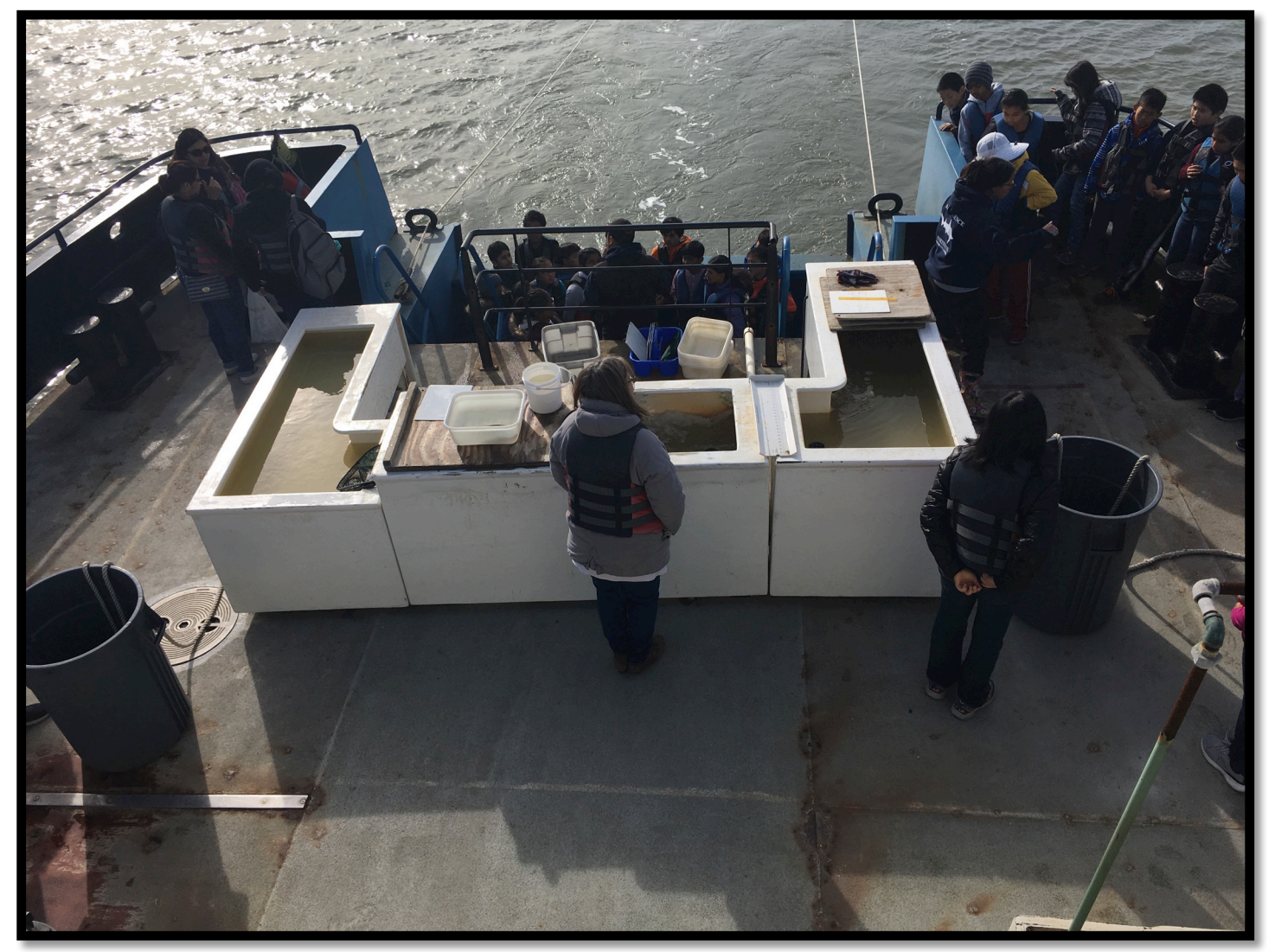

Figure 4. Photo of the holding tanks onboard the Robert G. Brownlee filled continuously with water from the Estuary, which holds captured marine species (Marine Science Institute, 2019. 


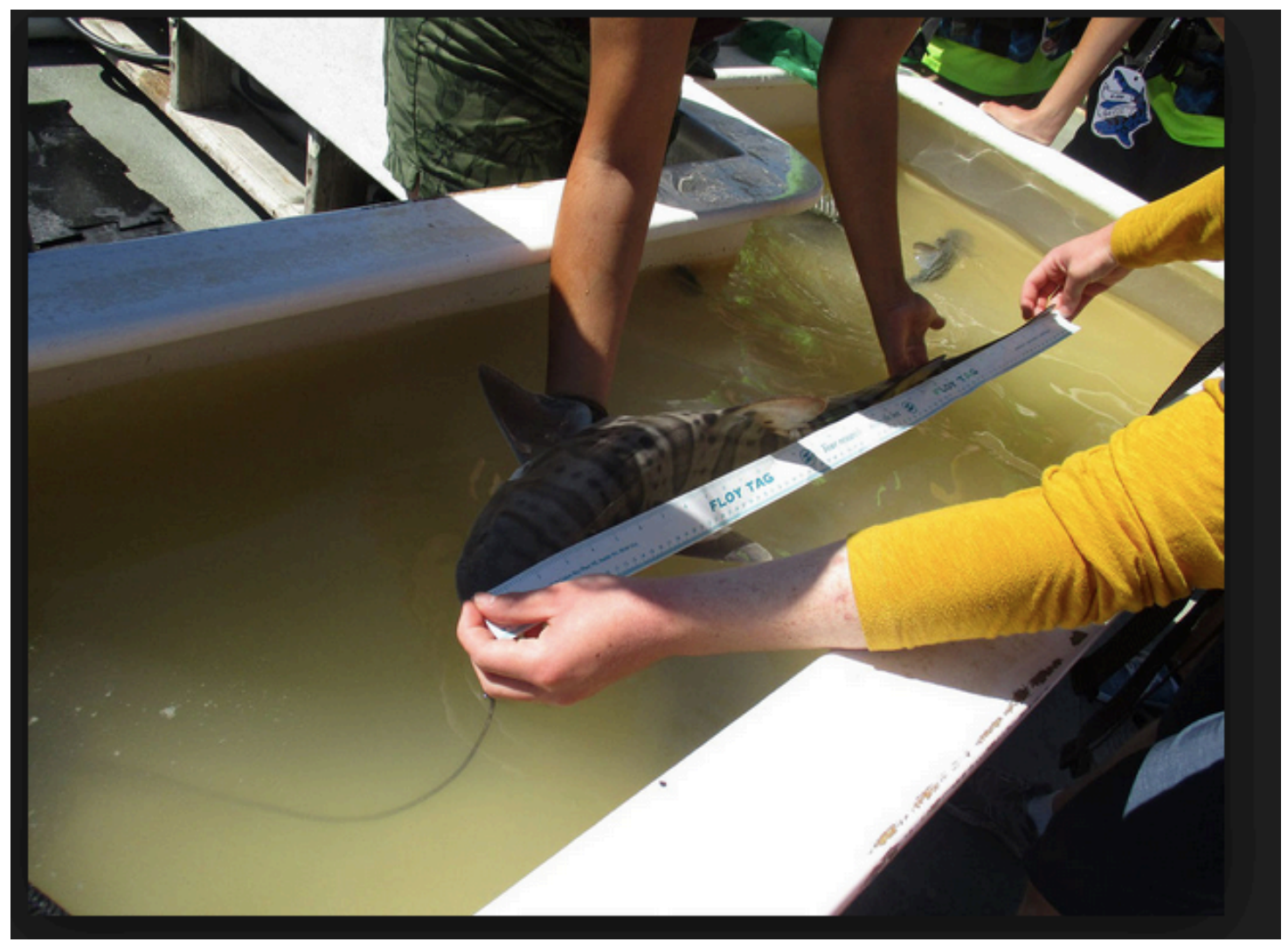

Figure 5. A leopard shark being measured in the port side holding tank onboard the Robert G. Brownlee by two Marine Science Institute instructors. Reprinted with permission from the Marine Science Institute (Marine Science Institute, 2019).

CPUE was calculated to analyze leopard shark relative abundance in the Estuary from 1998 to 2017. CPUE was defined as the total number of leopard sharks caught per day over the total hours trawled per day:

$$
C P U E=\frac{\sum \text { number of sharks caught }}{\sum \text { total trawl time (hours) }}
$$

Salinity and water temperature data were collected by the USGS from Redwood Creek, sample station 30, located at $37.5550^{\circ} \mathrm{N},-122.1900^{\circ} \mathrm{W}$ (Schraga, Nejad, Martin \& Cloern, 2018) (Figure 6). Salinity and water temperature data were analyzed between the years of 1998 and 2017. The depth at this site at mean low water is 12.8 meters. Abiotic 
data was measured in 1-meter increments from 1 to 13 meters at this location. Hydrology measurements at each depth did not vary considerably; therefore the average including measurements at all depths was analyzed in this study. Additional abiotic data is available to the public on their website (https://sfbay.wr.usgs.gov/access/wqdata/query/easy.html).

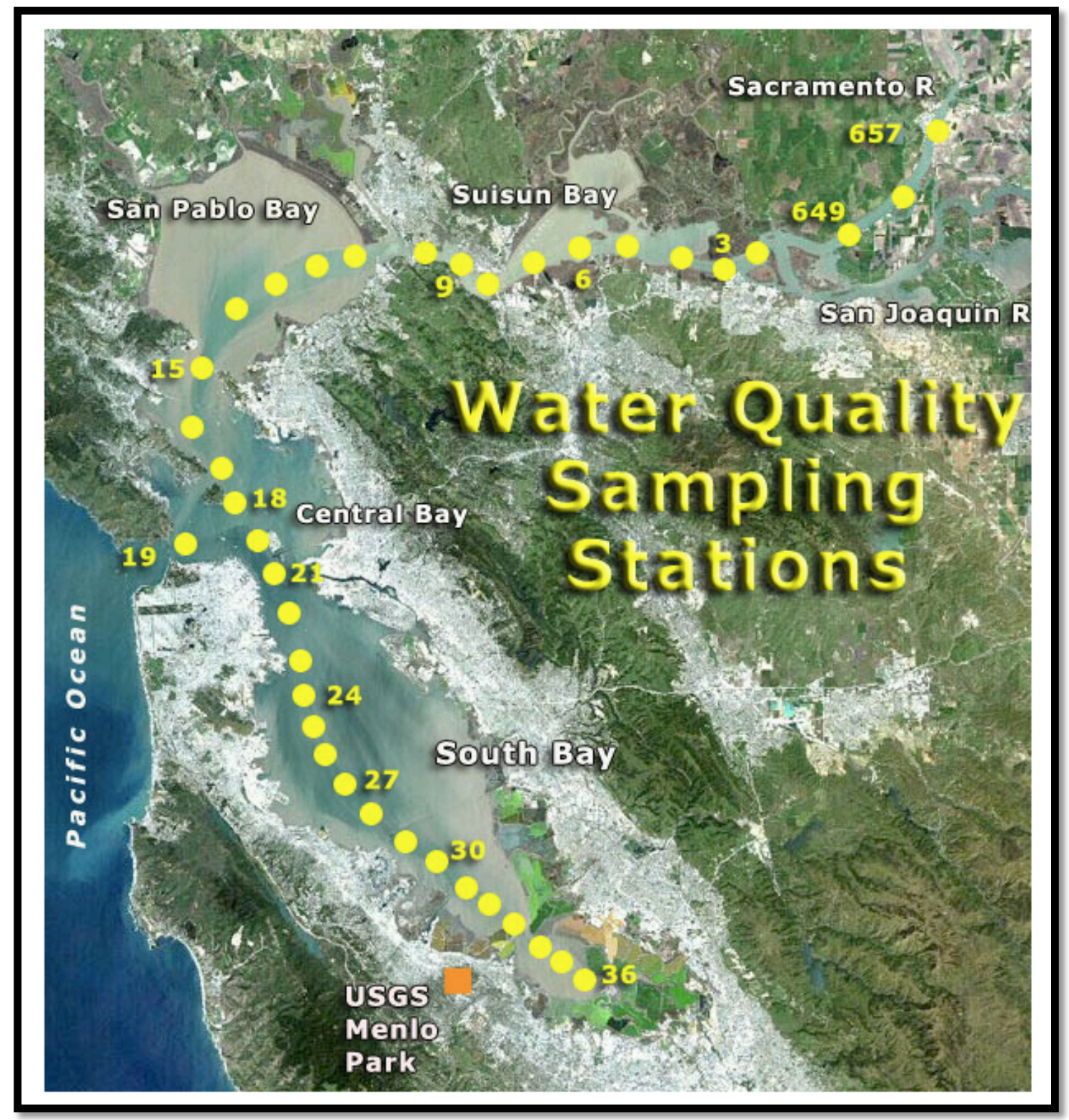

Figure 6. United States Geological Survey water quality sampling stations in the Estuary $(\mathrm{R}=$ river). Reprinted with permission from the United States Geological Survey (Schraga et al. 2018). 
Precipitation data for San Jose, California was collected from the National Oceanic and Atmospheric Administration's website (National Weather Service Forecast Office n.d.). Abiotic environmental data, including daily and monthly precipitation records, were publicly available on their website (https://w2.weather.gov/climate/xmacis.php?wfo=mtr). The San Jose precipitation marker chosen for this project was located within the closest proximity to MSI's trawling locations (Figure 7).

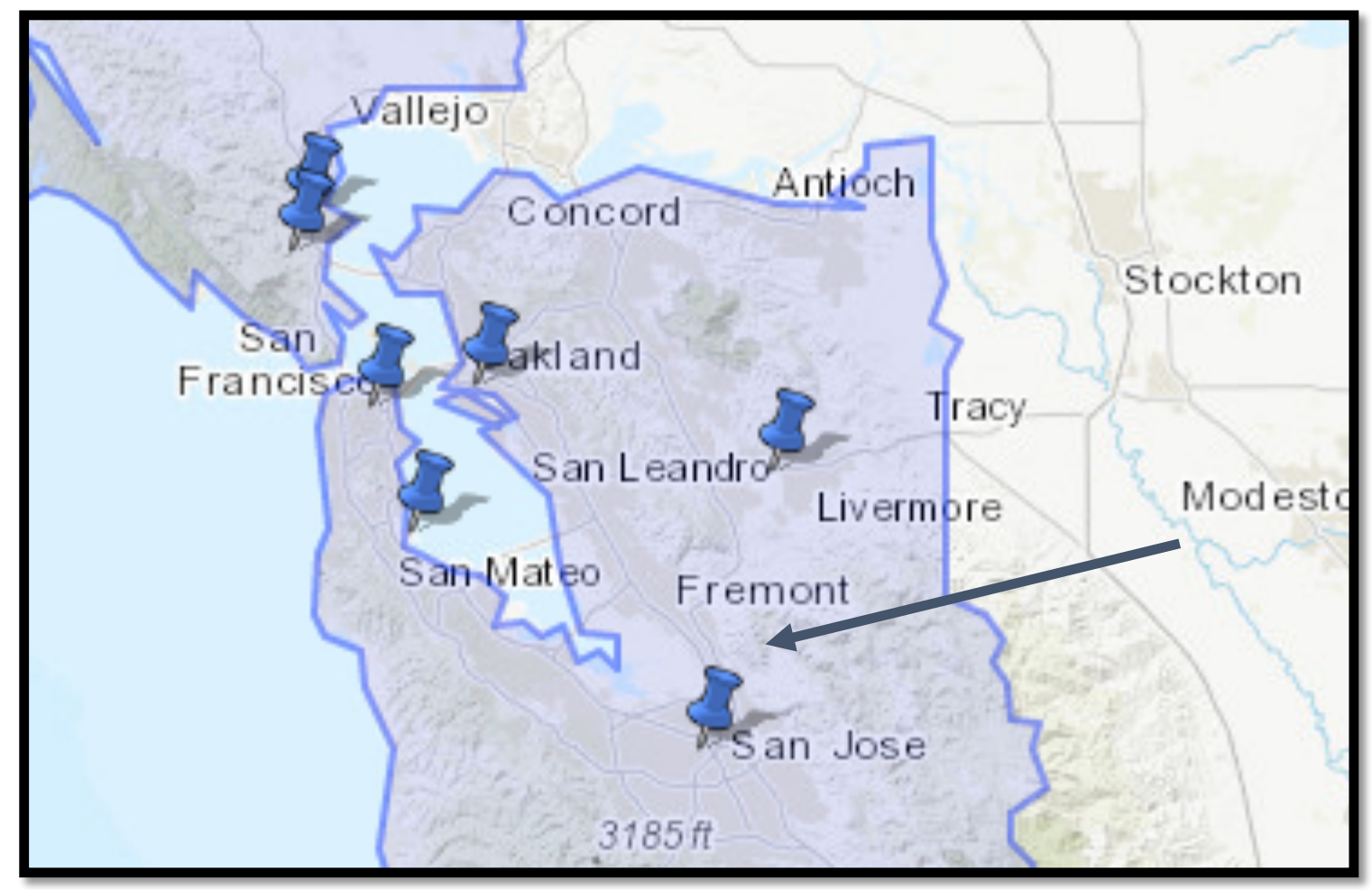

Figure 7. National Oceanic and Atmospheric Administration climatology sampling locations indicated by pushpins. The arrow indicates the sampling station where precipitation readings were collected for this study. Reprinted with permission from the National Weather Service Forecast Office (National Weather Service Forecast Office n.d.). 
It is important to note these limitations of the methods. First, and most importantly, the locations for trawling were not random. The vessel traveled to locations throughout the Bay deemed by the Captain to be safe, and to general locations set by boat manager. Trawling tended to occur within the deep water channel between the San Mateo-Hayward and Dumbarton Bridge (Figure 1). Thus, shallower sites were not well represented.

Second, the slow speed of the boat may have resulted in lower catch counts, but since this project was analyzing an index these limitations do not invalidate the results of this study. Finally, the dates for trawling were not randomly selected and most were in the summer. However, there were many hundreds of trips over the study period that provided a good characterization of both summer and winter seasons. In sum, the data collected were especially reflective of leopard shark abundance in deeper South Bay habitats.

\section{Data Analysis}

Data were analyzed using IBM SPSS Statistics Version 25. All independent variables (salinity, water temperature, and precipitation) were assessed for significant correlations with each other in order to remove redundant variables. For this study, summer was defined as April to August and winter was defined as December to March.

The relative abundance of leopard shark captures, as determined by CPUE, was used as the dependent variable in regression and non-parametric analyses of variance tests with all non-correlated independent variables. All variables were assessed for normality and homogeneity of variances, as appropriate. 
$\boldsymbol{C P U E}$. For all instances in which leopard shark CPUE was analyzed in this study, CPUE was defined as the total number of leopard sharks caught per day over the total hours trawled per day:

$$
C P U E=\frac{\sum \text { number of sharks caught }}{\sum \text { total trawl time (hours) }}
$$

The daily CPUE data set was not normal; therefore, the Spearman's rank order correlation test was performed to determine if there was a change in CPUE over time. Extreme values were removed from the daily CPUE data set before statistical analysis.

To test variation in leopard shark CPUE between months over the study period, the mean CPUE was calculated for each month of the year (January to December) and analyzed using the independent samples Kruskal-Wallis H test. A Mann-Whitney U test was run to compare CPUE between months that indicated similar CPUE mean values over time.

A Kruskal-Wallis $\mathrm{H}$ test was run to test interannual variation in CPUE using the daily CPUE data set. A post hoc pairwise test indicated years in which variation in CPUE was present.

To assess whether leopard shark presence changed significantly over time, the average of the average CPUE was calculated for each month. This measure was used to reduce variability and the influence of extreme values. Using these data, a regression test was run to test whether the annual mean leopard shark CPUE during summer months (April through August) varied significantly between 1998 and 2017. 
Analysis of environmental conditions in the SFE. The average salinity, measured in practical salinity units (psu), by year during summer and winter months was calculated and used as independent variables in regression analyses to determine significant correlations over time.

The average temperature $\left({ }^{\circ} \mathrm{C}\right)$ in the southern portion of the Estuary was calculated for both summer and winter months from 1998 to 2017 following the same procedure as the salinity calculations in this study. The average of the average temperature by year (1998 to 2017) in winter and summer months was calculated and were used as independent variables in regression analyses against year to determine correlation.

Annual precipitation (millimeters) was calculated from 1998 to 2017 and used as an independent variable in regression analyses against year to determine correlation. These data were used to visually analyze whether a relationship existed between annual precipitation and leopard shark CPUE.

Lastly, two separate regression tests were run to determine whether summer salinity and summer water temperature had an effect on leopard shark abundance during summer months. Additionally, a univariate analysis of variance was run to analyze leopard shark CPUE acquired during summer months from 1998 to 2017 using salinity as a covariate. The average of the average CPUE was calculated to run these tests using catch data from summer months between 1998 and 2017. Salinity data used in this analysis were calculated in the same manner. 


\section{Results}

Leopard sharks were collected between 1998 and 2017 with a total of 155 hours $(M=$ 7.78, $S E=1.25$, Range $=22.67)$ of sampling using an otter trawl. A total of 303 females with a mean size of $509.8 \mathrm{~mm}(S E=42.36$, Range $=3340)$ and 420 males with a mean size $615.82 \mathrm{~mm}(S E=22.23$, Range $=947.5)$ were analyzed. There was a strong positive correlation between leopard shark CPUE and year, which showed a slight but detectable increase in relative abundance over time $\left(r_{s}(488)=0.233, p<0.001\right)$ (Figure 8).

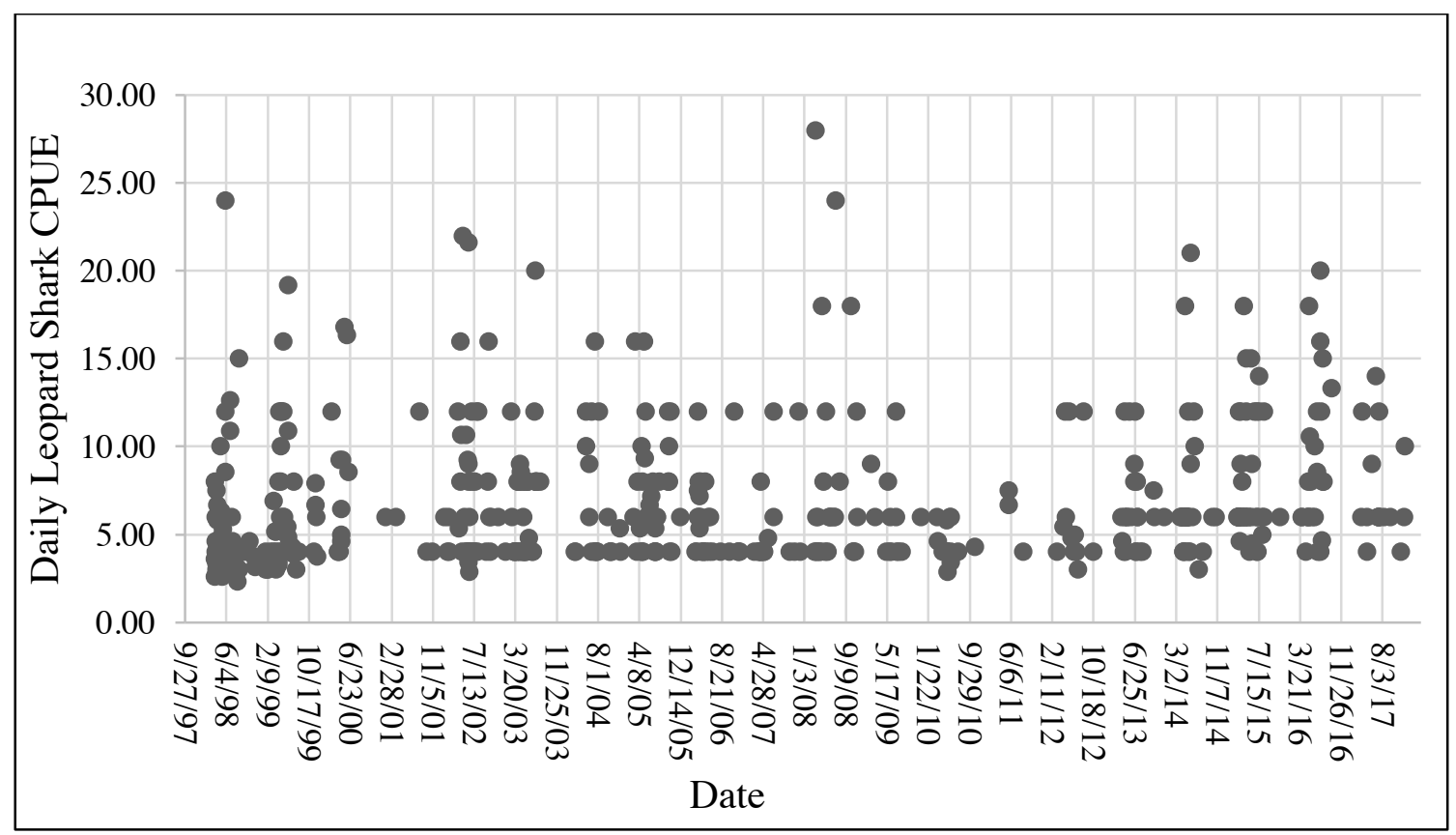

Figure 8. Scatterplot showing daily CPUE of leopard sharks captured between 1998 and 2017 by the Marine Science Institute.

The distribution of leopard sharks significantly varied between some months, $H(11)$ $=19.82, p=0.048)$. A post hoc pairwise comparison revealed significant differences between: January and May $(p=0.007)$, January and June $(p=0.035)$, January and July ( $p$ $=0.041)$, December and May $(p=0.006)$, October and May $(p=0.004)$, October and 
June $(p=0.044)$, and March and May $(p=0.020)$ (Figure 9). Further analysis of CPUE variation between the months of April to August indicated a slight measurable difference between April and May $(U=3770.5, p=0.046)$, but overall the median CPUE in spring and summer months was higher than the median CPUE in fall and winter months (Table $1)$.

Table 1. Mean leopard shark CPUE values by month calculated using daily CPUE data from the Marine Science Institute's index from 1998 to 2017.

\begin{tabular}{|l|l|l|l|}
\hline Month & Mean & $\underline{\text { SD }}$ \\
January & 4.5 & 1.225 & 6 \\
February & 6.25 & 3.535 & 10 \\
March & 6.34 & 3.919 & 56 \\
April & 6.38 & 3.345 & 94 \\
May & 7.62 & 4.509 & 96 \\
June & 7.11 & 3.63 & 68 \\
July & 7.09 & 4.523 & 69 \\
August & 7.31 & 3.878 & 26 \\
September & 6.48 & 3.37 & 7 \\
October & 6.61 & 3.849 & 27 \\
November & 6.22 & 3.145 & 16 \\
December & 5.55 & 1.769 & 11 \\
\hline
\end{tabular}




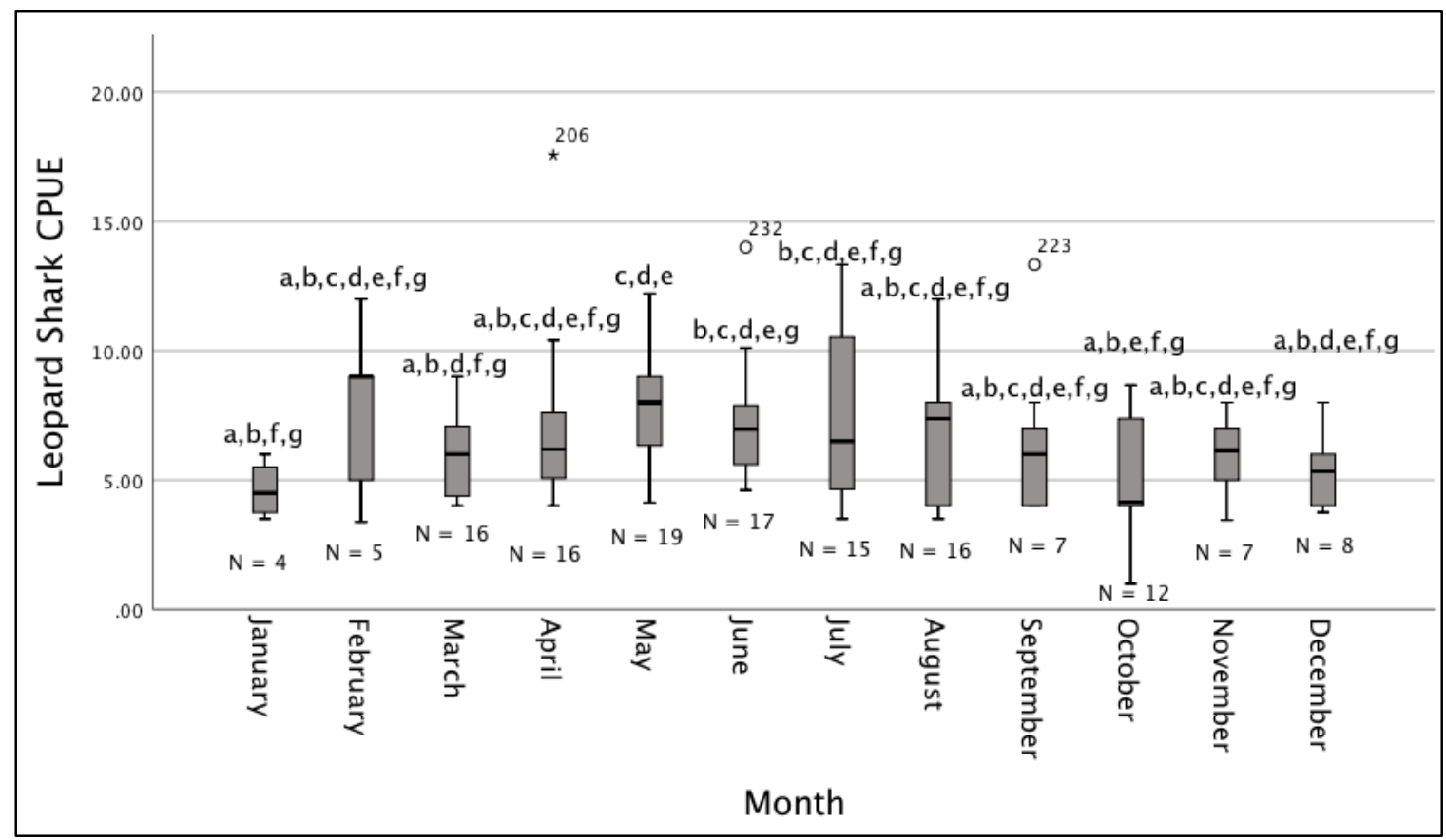

Figure 9. Leopard shark mean CPUE values evaluated by month from 1998 to 2017. Means with different letters are significantly different. $\mathrm{N}=$ sample size analyzed annually. Whiskers running from each box represent minimum and maximum values. Unfilled circles represent suspected outliers. Asterisks represent extreme outliers.

An analysis of annual catch data using data accumulated from April to August of each year during the study period indicated interannual variation in CPUE between many years, $(H=45.22, p=0.001)$ (Figure 10) (Appendix). The annual mean CPUE was lowest for the years $2006(M=5.369, S E=1.022), 2007(M=5.480, S E=1.251)$, and $2010(M=4.372, S E=1.193)$, and highest for the years $2008(\mathrm{M}=8.286, S E=1.057)$, $2015(M=8.304, S E=0.748)$, and $2016(M=8.993, S E=0.825)$. 


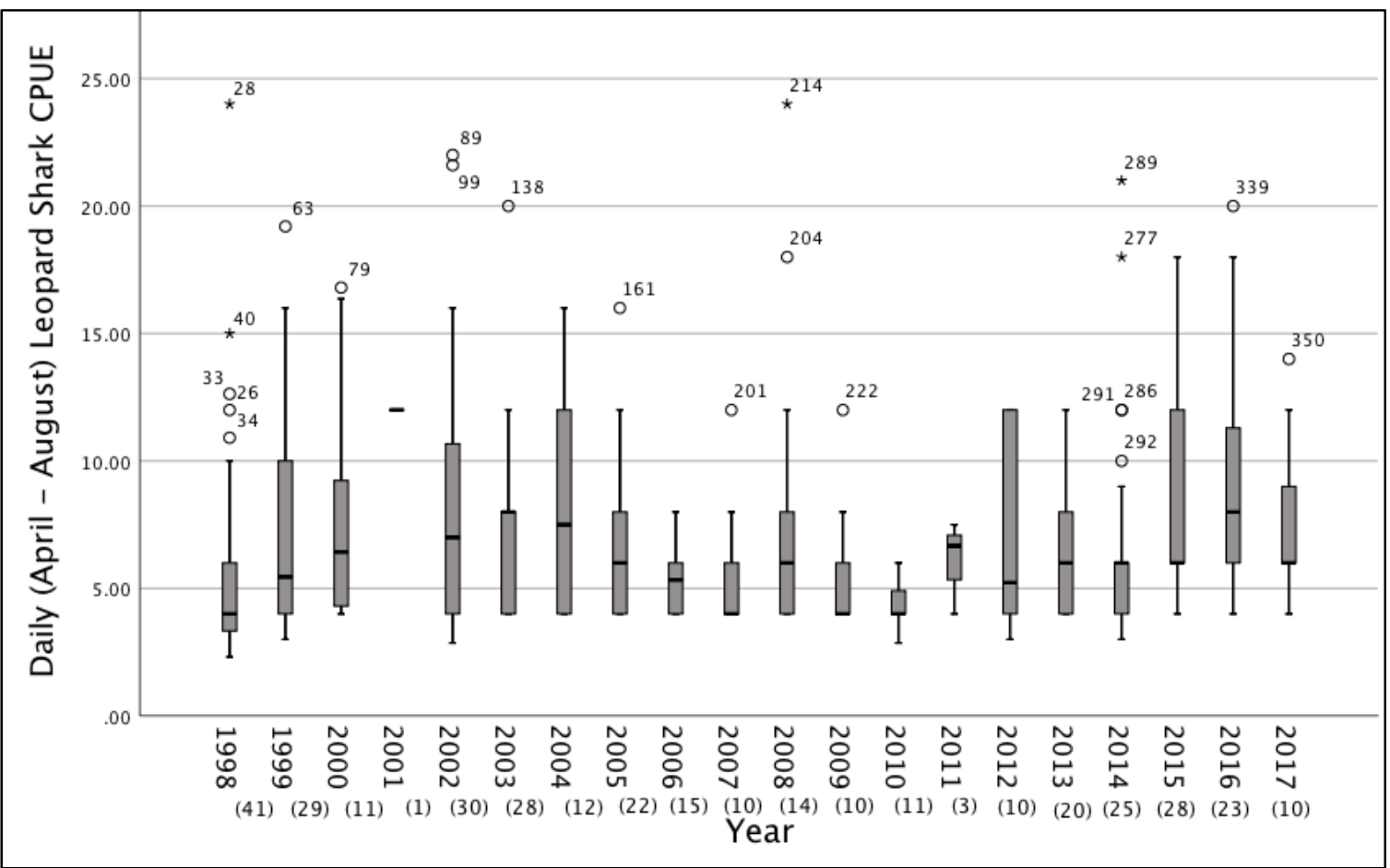

Figure 10. April to August leopard shark CPUE results from Kruskal-Wallis test on variation between years. Numbers in parentheses below each year represents the sample size analyzed per year. Whiskers running from each box represent minimum and maximum values. Unfilled circles represent suspected outliers. Asterisks represent extreme outliers.

Despite differences between years, there was no trend over time in the average CPUE when analyzed annually using the months of April to August over the study period, $\left(r^{2}=\right.$ $0.026, F(1,18)=0.479, p=0.498)($ Figure 11). 


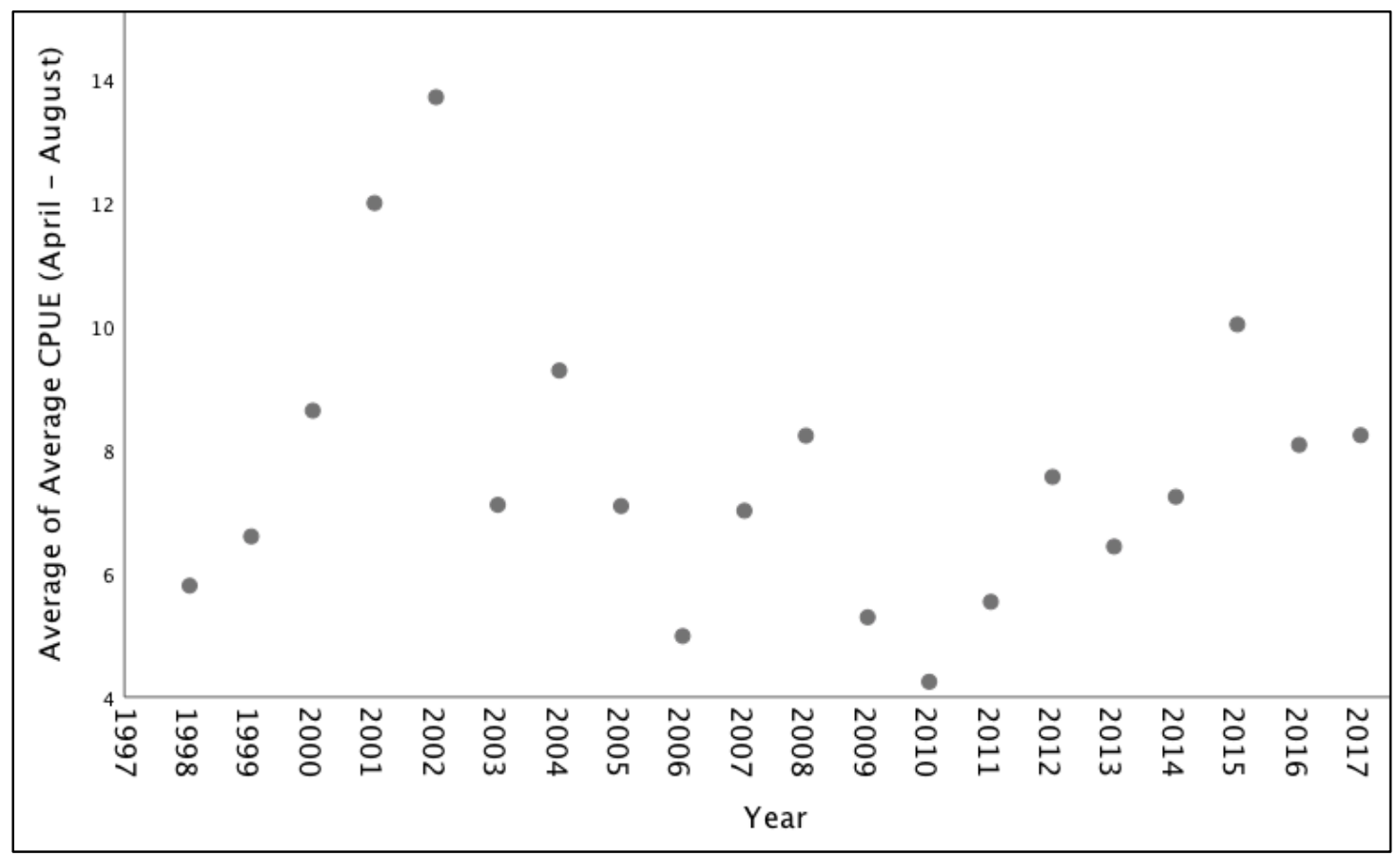

Figure 11. Scatterplot showing results from a regression test, which analyzed annual mean leopard shark CPUE from 1998 to 2017 using data from the months of April to August.

Total annual precipitation tended to decline during the study period $\left(R^{2}=0.155\right.$, $F(1,19)=3.475, p=0.078)($ Figure 12$)$.

The average salinity for the months of April to August during the study period showed no trend over time $\left(R^{2}=0.136, F(1,18)=2.85, p=0.108\right)$ (Figure 12). Salinity was lowest in the years 1998, 2006, 2011 , and 2017 (salinity $\leq 22$ psu) and highest in the years 2014 and 2016 (salinity $\geq 30$ psu). 


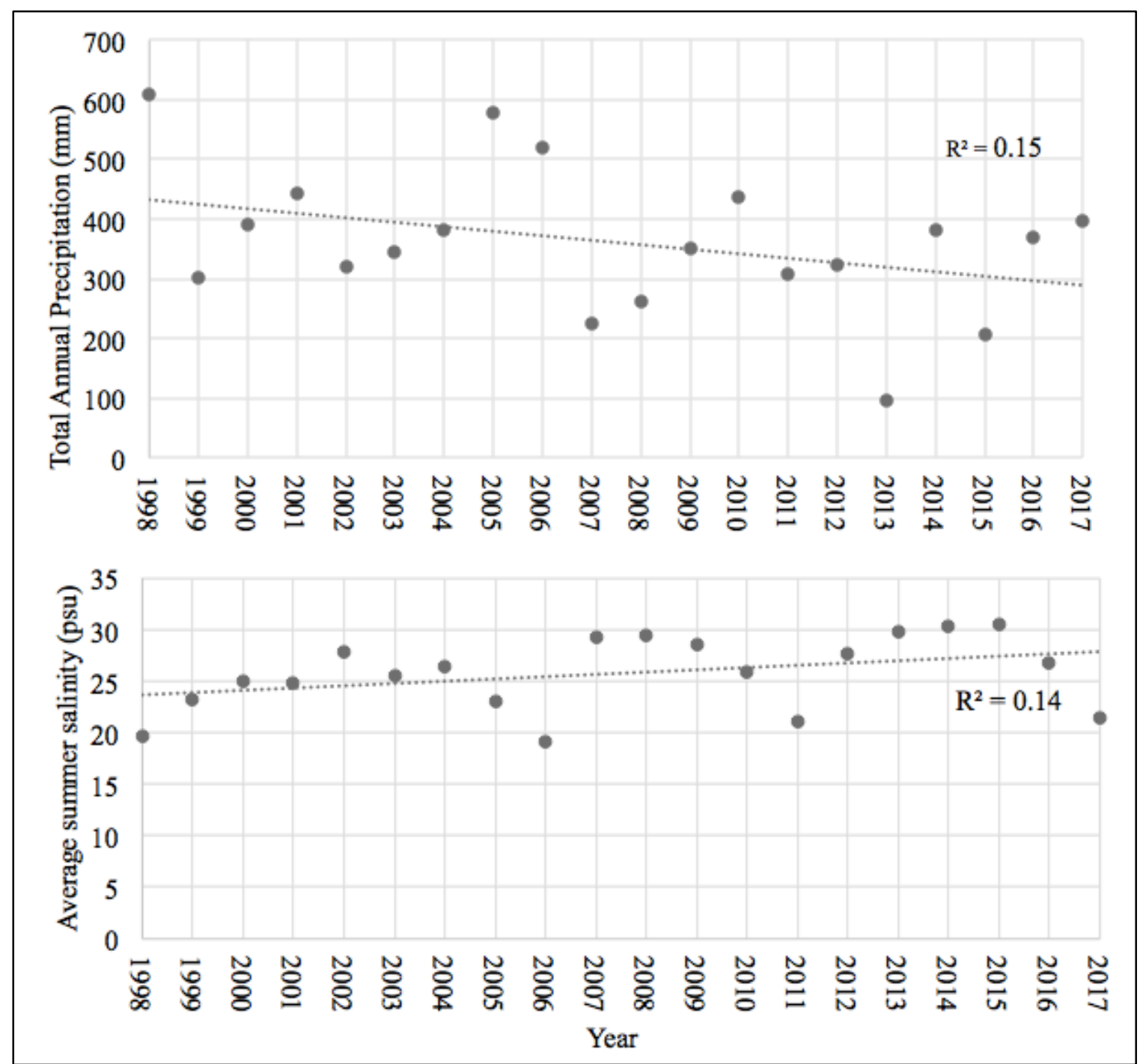

Figure 12. Annual salinity averages for the months of April to August from 1998 to 2017 obtained from USGS station 30 in the SFE. Annual rainfall (in millimeters) for San Jose, CA provided by the National Weather Service Forecast Office.

The average water temperature between the months of April to August from 1998 to 2017 increased slightly over time $\left(R^{2}=0.271, F(1,18)=6.715, p=0.018\right)$ (Figure 13).

The annual average water temperature was lowest in the year $1999\left(16.01{ }^{\circ} \mathrm{C}\right)$ and highest in the year $2009\left(20.88^{\circ} \mathrm{C}\right)$. 
The annual average winter (December to March) water temperature was more variable and showed a tendency toward a slight increase over time $\left(R^{2}=0.154, F(1,18)=\right.$ $3.269, p=0.087$ ). Winter water temperature was lowest in 1999 and 2002 (temperature $\leq$ $11.50{ }^{\circ} \mathrm{C}$ ) and was highest in 2003 and 2017 (temperature $\geq 12.60^{\circ} \mathrm{C}$ ) (Figure 13). 


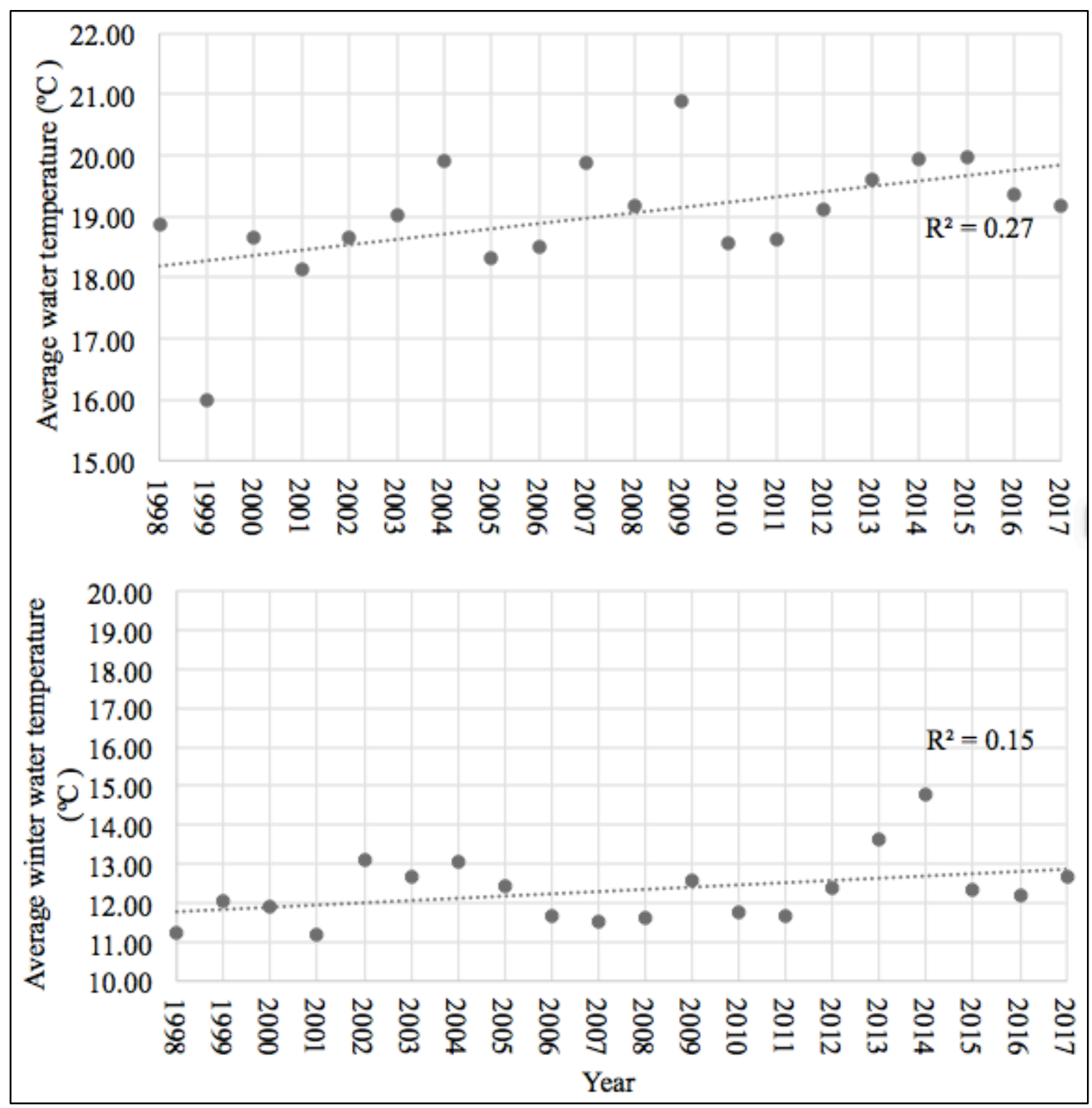

Figure 13. Annual (April to August) water temperature averages from 1998 to 2017 obtained from USGS station 30 in the SFE. Annual winter (December to March) water temperature from 1998 to 2017 obtained from USGS station 30 in the SFE.

There was no statistical relationship between the annual average summer CPUE and summer salinity $\left(R^{2}=0.092, F(1,18)=1.826, p=0.193\right)$. There was no relationship between the annual average summer CPUE and summer water temperature $\left(R^{2}=0.0002\right.$, 
$F(1,18)=0.005, p=0.946)$. CPUE tended to decrease as salinity decreased during summer months $(F(1,4)=3.486, p=0.066)$ (Figure 14).

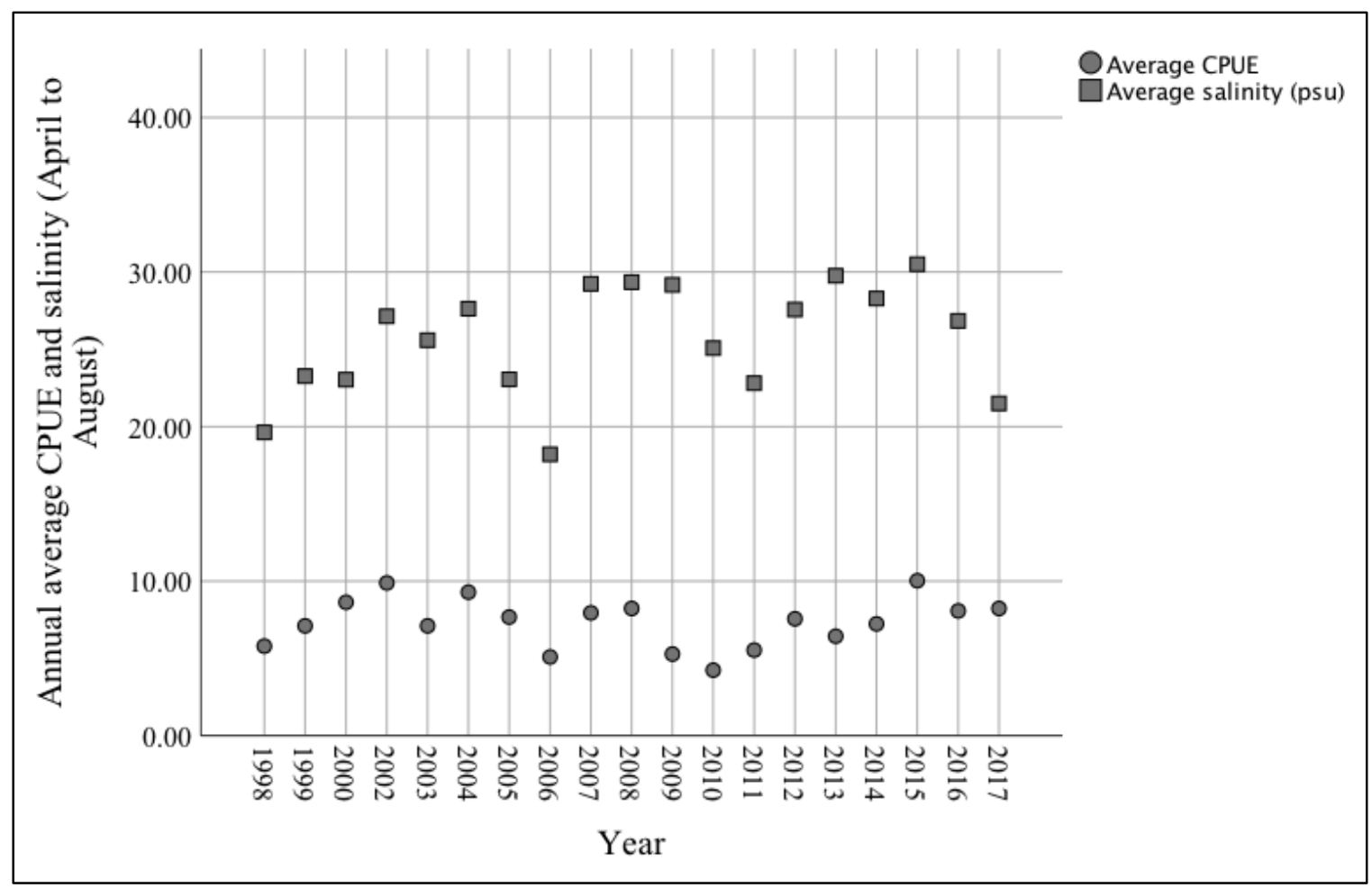

Figure 14. Scatterplot illustrating the trend in leopard shark CPUE (squares) and salinity (circles) using data from the months of April to August between 1998 and 2017.

Figure 15 provides a visual on the location of leopard sharks captured in 2017 during the parturition and breeding season at the study site. 


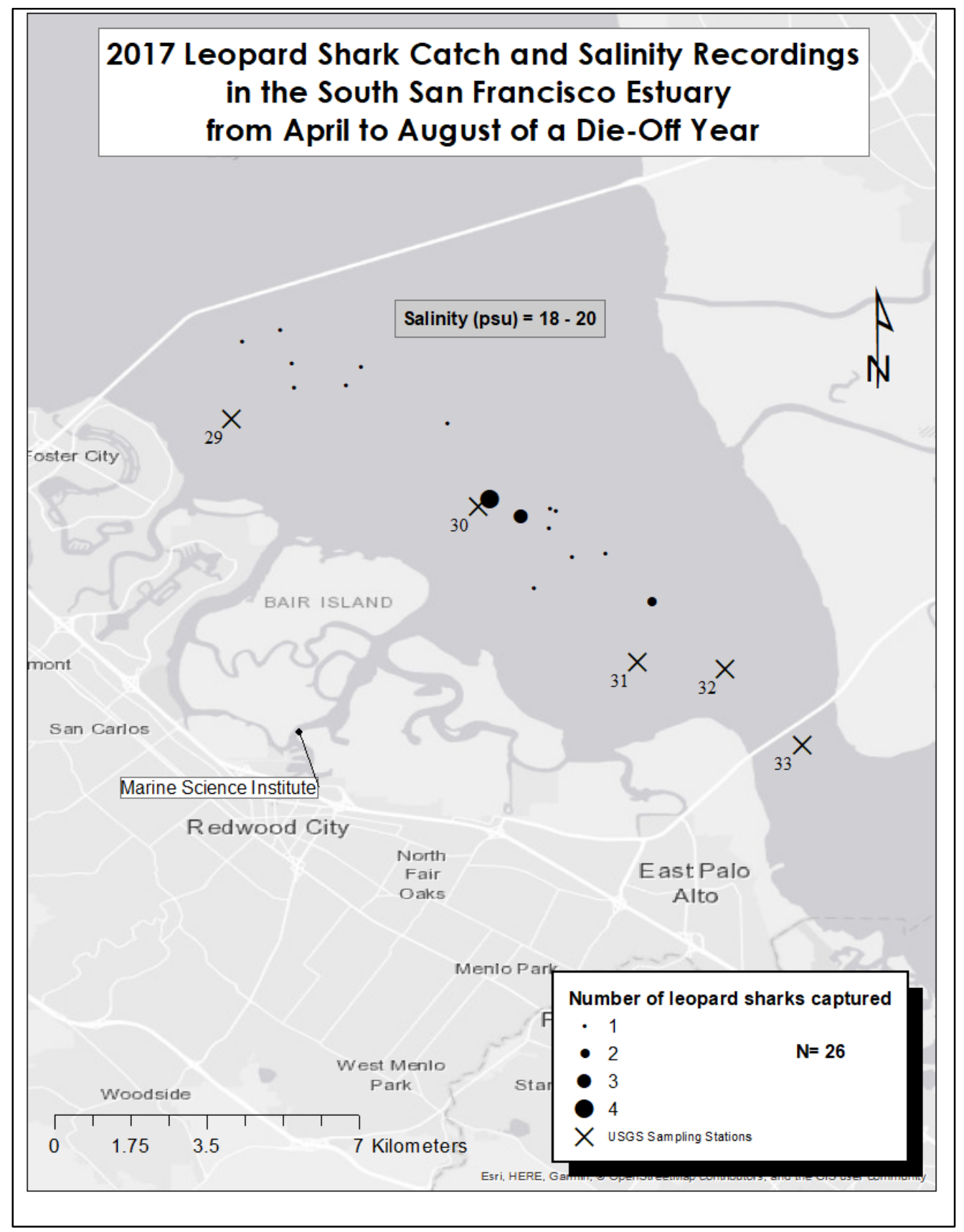

Figure 15. A map showing individual leopard sharks captured in the SFE by the Marine Science Institute between April and August of 2017. The average salinity (psu) for the months of April to August is also included. 


\section{Discussion}

A primary goal of this study was to assess the population trend for leopard sharks in the SFE. Data from 1998 to 2017 indicated that the abundance of leopard sharks in the SFE has remained relatively stable over this period despite significant interannual variability in CPUE, a rise in spring and summer water temperatures over time, and variable salinity conditions (between 20-30 psu). These data were reflective of leopard shark abundance in the deep water channel in the SFE. Since trawling locations were determined by the captain and dependent on the tide, weather conditions, and length of the educational program, data collection was limited to this particular region of the Estuary.

As partially euryhaline organisms, leopard sharks can tolerate a wide range of salinity and temperature differences compared to other elasmobranch species (Carlisle \& Starr, 2009; Hopkins \& Cech, 2003; Smith \& Abramson, 1990). As abiotic elements change with the seasons throughout the year, leopard sharks follow water conditions that are most favorable for survival, which includes regions with salinity levels above 18 psu and temperatures greater than $10^{\circ} \mathrm{C}$ (Hopkins \& Cech, 2003). Over the 20-year study period, the SFE typically provided these conditions that support leopard sharks.

This study found a greater relative abundance of sharks in the SFE during the months of April through August compared to winter months, December through March. Studies show that the Estuary provides a variety of favorable habitats that serve as parturition, breeding, and nursery areas in addition to an abundance of prey availability (Russo, 2019). Leopard sharks are especially abundant in shallow, warm water within the Estuary 
during spring and summer months (Hight \& Lowe, 2007; Nosal et al., 2013; Russo, 2019), which is likely because they venture to this region of the Estuary during late spring and early summer to pup (Fish et al., 2011; Hobbs et al., 2015; Nosal et al., 2013). They can be found from deep water channels to shallow habitats along the shores of the Estuary depending on factors such as salinity and water temperature throughout the year (Hobbs et al., 2015; Hopkins \& Cech, 2003; Smith \& Horeczko, 2007). Analysis of CPUE from this study showed congruence with other analyses involving migration patterns of leopard sharks during spring and summer months in similar estuarine environments along the Pacific west coast (Carlisle \& Starr, 2009; Hopkins \& Cech, 2003; Smith \& Abramson, 1990).

Compared with other bays and estuaries where leopard sharks typically congregate only seasonally, the Estuary is particularly notable because of its suggested partially resident population, which remains within the confines of the Estuary year-round (Russo, 2019; Smith, 2001). Leopard sharks were captured perennially by the Marine Science Institute in the SFE, which further supports the contention that some sharks remain in the Bay throughout the year rather than migrating out as conditions change with the seasons. If and when individuals do leave, they tend to travel to estuaries and bays with similar habitats between Elkhorn Slough and Humboldt Bay rather than to regions south of Monterey, CA (Barker et al., 2015; Smith \& Abramson, 1990).

Why some sharks remain in the Estuary and others do not is not fully understood. In neighboring Elkhorn Slough, Talent (1985) and Carlisle et al. (2007) found that larger sharks $(>100 \mathrm{~cm})$ were more abundant in the winter and spring, with both large and small 
sharks showing similar abundance during the summer and fall. Though size was not statistically analyzed in this study due to a lack of consistent data over the study period, a majority of leopard sharks caught by the Marine Science Institute during the study period had an overall total length less than $100 \mathrm{~cm}$, indicative of younger animals (Ackerman, 1971; Kusher et al., 1992). It should be noted that the trawl method used to capture sharks for this study may have resulted in catching animals of a smaller or even larger size, yet the overall small size of sharks captured over the study period may indicate that the juvenile shark population utilizes the SFE year-round.

Leopard sharks tend to form schools of similar size and sex (Barker et al., 2015; Lewallen \& Anderson, 2007; Smith, 2001). While the sex of leopard sharks was not statistically analyzed in this study, visual observation of the data set indicated a greater number of males compared to females captured over the study period. A total of 420 males and 303 females were captured between 1998 and 2017. Future studies could analyze the sex distribution of these sharks in this particular region of the Estuary in both the deep water channel and the shallow regions.

Leopard shark populations during summer months varied greatly between years at the study site, especially in two notable die-off years, 2006 and 2011. Shark movement in and out of the SFE could be a partial explanation. However, while seasonal migrations of leopard sharks in and out of bay and estuarine habitats are mentioned in numerous studies, many of the sharks observed in these studies tended to show site fidelity, indicating that they should return in similar abundances each year (Barker et al., 2015; Carlisle \& Starr, 2009; Ebert \& Ebert, 2005; Nosal et al., 2013). Additional research 
suggests that minimal population exchange occurs between the northern and southern California stocks, with the dividing line between these stocks being Elkhorn Slough (Lewallen \& Anderson, 2007; Smith, 2001). Site fidelity and minimal population exchange between northern and southern California leopard shark stocks suggest that alternate variables are influencing leopard shark population fluctuations between years.

Data gathered over a period of 20 years indicated an increase in summer (April to August) water temperature and a decrease in annual precipitation. Warmer water holds less oxygen, as does water with higher salinities. Dissolved oxygen is one important abiotic factor that determines the distribution of leopard sharks in their distinct habitats (Desmond et al., 2002; Ebert, 1986; Fish et al., 2011; Hight \& Lowe, 2007; Hopkins \& Cech, 2003; Mejia et al., 2008; Miklos et al., 2003). The combination of these hydrological conditions may discourage the migration of leopard sharks into the Estuary, which may partially explain variation in CPUE between years.

Mass die-offs also show populations are strongly affected by local demographic factors that could be driven by environmental conditions. Salinity is a critical environmental variable for leopard sharks and declines in annual CPUE appeared to coincide with declines in salinity during the parturition and breeding seasons. In the deep water channel where abiotic data was collected for this study, salinity measurements during the spring and summer months of years in which die-offs occurred were recorded at or below 23.0 psu. Dowd et al. (2010) determined water salinities at $80 \%$ of seawater $(\leq 27.6 \mathrm{psu})$ were enough to cause leopard shark cells to go into osmotic stress, in addition to experiencing an increase in urea loss (Dowd et al., 2010). While partially 
euryhaline sharks such as the leopard shark have adapted to withstand a range of salinities in estuarine environments, exposure to lower salinities over a long period of time have the potential to cause physiological harm to the organism or may leave it vulnerable to infection. Future studies could more closely analyze the relationship between salinity and leopard shark abundance by collecting data from both the deep water and shallow regions of the Estuary.

M. avidus is the ciliate protozoan shown to be proximally responsible for the elasmobranch die-off in the San Francisco Bay in 2011. It lives in seawater and enters its host through the skin and/or gills where it then spreads throughout its host through the bloodstream ultimately leading to the death of its victim (Jung et al., 2007; Retallack et al., 2018). Because leopard sharks tend to form schools of similar sex and age (Barker et al., 2015; Lewallen \& Anderson, 2007; Smith, 2001), they are susceptible to infection from M. avidus, which favors schooling fish (Jung et al., 2007). When abiotic environmental conditions become unfavorable and/or sharks are unable to evade changing conditions, overcompensating to maintain physiological processes may result in episodes of fatalities. No mention of mass die-offs involving elasmobranchs have been reported in neighboring Bays or estuaries that are frequented by elasmobranch species (per communications with Dr. Okihiro). This may indicate that M. avidus is not being transmitted to other populations, possibly due to the theory that the leopard shark population in the Estuary is largely residential. This may be because the infected sharks die before they travel to other locations outside of the Estuary, or this may provide further evidence that the Estuary leopard shark population is genetically distinct from other 
subpopulations and particularly vulnerable to the ciliate protozoan responsible for the 2017 die-off. 


\section{Recommendations}

The Estuary is the largest estuary available to leopard sharks within their range and hosts a variety of favorable habitats that serve as first and secondary nurseries, parturition and breeding sites, as well as perennial residences (Russo, 2019). While estuarine environments are prone to interannual fluctuations in salinity and water temperature, extreme fluctuations can result in the dispersal and/or die-off of leopard sharks, which can have cascading effects on other trophic levels. Given the connection between low salinity and leopard shark die-offs, a continuation of the size limit on catches, and a potential no take, especially during the parturition and breeding season following heavy winter rains is recommended to avoid contributing to population losses that may occur due to environmental conditions. Future studies could analyze environmental variables, food abundance, and habitat preferences that attract these juvenile sharks to this region of the Estuary, providing biologists and policy makers with useful data that could lead to the implementation of further protections for key native species in this section of the Estuary.

Additional studies could more closely analyze the relationship between habitat variables and leopard sharks in the Estuary by incorporating salinity and water temperature readings from outside of the deep water channel.

With the increase in technology that enables public participation in data collection, analysis, and interpretation, scientists have a unique opportunity to utilize the assistance of concerned citizens. While data collected by citizens present limitations, community science monitoring in the world of marine science has proved successful in coastal management and invasive marine species monitoring (Bear, 2016). Applications such as 
iNaturalist have already proved useful in tracking when and where elasmobranchs are turning up dead along the shores of the Estuary. Visual observations and comments from community scientists regarding the sex, size, and appearance of beached sharks can prove useful to scientists researching the root cause of these die-offs.

Future research that could help managers protect leopard shark populations includes. Analyzing how food web regulating predators such as the leopard sharks are faring as environmental conditions rapidly change due to human induced climate change is essential to the future of estuarine habitats. 


\section{Literature Cited}

Ackerman, T. (1971). Contributions to the biology of the leopard shark (Triakis semifasciata) (Girard) in Elkhorn Slough, Monterey Bay, California (master's thesis). Sacramento State College.

The Bay Institute of San Francisco. (1998). From the sierra to the sea: The ecological history of the San Francisco Bay-Delta watershed. Retrieved from https://bayecotarium.org/wp-content/uploads/tbi_sierra-to-the-sea-1998.pdf.

Barker, A. M., Nosal, A. P., Lewallen, E. A., \& Burton, R. S. (2015).

Genetic structure of leopard shark (Triakis semifasciata) populations along the Pacific coast of North America. Journal of Experimental Marine Biology and Ecology, 472, 151-157.

Bascompte, J., Melian, C. J., \& Sala, E. (2005). Interaction strength combinations and the overfishing of a marine food web. PNAS, 102(15), 5443-5447.

Bear, M. (2016). Perspectives in marine citizen science. Journal of Microbiology and Biology Education, 17(1), 56-59.

Brar, N. K., Waggoner, C., Reyes, J. A., Fairey, R., \& Kelley, K. M. (2009). Evidence for thyroid endocrine disruption in wild fish in San Francisco Estuary, California, USA. Relationships to contaminant exposures. Aquatic Toxicology, 96, 203-215.

Bornatowski, H., Navia, A. F., Braga, R. R., Abilhoa, V., \& Correa, M.

M. (2014). Ecological importance of sharks and rays in a structural foodweb analysis in southern Brazil. ICES Journal of Marine Science, 71(7), 1586-1592.

California Department of Fish and Wildlife. (2019). Current ocean recreational fishing regulations: San Francisco Bay District. Retrieved from https://www.wildlife.ca.gov/Fishing/Ocean/Regulations/Fishing-Map/sf-bay.

Carlisle, A., King, A., Cailliet, G. M., \& Brennan, J. S. (2007). Long-term trends in catch composition from elasmobranch derbies in Elkhorn Slough, California. Marine Fisheries Review, 69(1), 25-45.

Carlisle, A. B. \& Starr, R. M. (2009). Habitat use, residency, and seasonal distribution of leopard sharks Triakis semifasciata in Elkhorn Slough, California. Marine Ecology Progress Series, 380, 213-228.

Castro, Jose I. (1983). The sharks of North American waters. Texas: Texas A\&M University Press. 
Castro, Jose I. (2011). The sharks of North America. New York, New York: Oxford University Press, Inc.

Cohen, Andrew. (2001). An introduction to the San Francisco Estuary. Oakland, CA: San Francisco Estuary Project. Retrieved from https://sfestuary.org/wpcontent/uploads/2012/12/Intro-to-SF-Estuary-PDF.pdf.

Cook, Jonathan D. (2012). Spatial and temporal trends of fishes and aquatic invertebrates in a restored salt march, San Francisco Estuary, CA (master's thesis). University of California, Davis.

Davis, Jay A., May, Michael D., Greenfield, Ben K., Fairey R., Roberts, C., Ickikawa, G., Stoelting, Matt S., Becker, Jonathan S., Tjeerdema, \& Ronald S. (2002). Contaminant concentrations in sport fish from San Francisco Estuary, 1997. Marine Pollution Bulletin, 44, 1117-1129.

Davis, Jay A., Hetzel F., Oram J. J., \& McKee L. J. (2007). Polychlorinated biphenyls (PCBs) in San Francisco Estuary. Environmental Research, 105, 67-86.

Desmond, J. S., Deutschman, D. H., \& Zedler, J. B. (2002). Spatial and temporal variation in estuarine fish and invertebrate assemblages: analysis of an 11-year data set. Estuaries, 25(4), 552-589.

Dowd, W. W., Harris, B. N., Cech, J. J. Jr., \& Kultz, D. (2010). Proteomic and physiological responses of leopard sharks (Triakis semifasciata) to salinity change. The Journal of Experimental Biology, 213, 210-224.

Ebert, D. A. (1986). Observations on the elasmobranch assemblage of San Francisco Bay. California Fish and Game, 72(4), 244-249.

Ebert, D. A. (2003). Sharks, rays, and chimeras of California. Berkeley, CA: University of California Press.

Ebert, David A., Ebert, \& Thomas B. (2005). Reproduction, diet and habitat use of leopard sharks, Triakis semifasciata (Girard), in Humboldt Bay, California, USA. Marine and Freshwater Research, 56, 1089-1098.

Farrer, Deborah A. (2009). Northern range extension of the leopard shark, Triakis semifasciata. California Fish and Game, 95(1), 62-64.

Fish, M., Messineo, J., \& Hieb, K. (2011). 2011 Bay study fishes annual status and trends report for the San Francisco Estuary. California Department of Fish and Wildlife IEP Newsletter, 26(1), 30-44. 
Gunther, A., Swanson, C., Collins, J., Davis, J., Nur, N., Vorster, P., Smetak, K., Jabusch, T., \& Becker, G. (2011). The state of the San Francisco Bay. Oakland, CA: San Francisco Estuary Partnership.

Harikrishnan, R., Kim, J., Kim, M., Dharaneedharan, S., Kim, D., Song, C., Balasundaram, C., \& Heo, M. (2012). Effect of dietary supplementation with Suaeda maritima on blood physiology, innate immune response, and diseases resistance in olive flounder against Miamiensis avidus. Experimental Parasitology, 131(2), 195 203.

Herald, Earl S., Ripley, \& Ellis W. (1951). The relative abundance of sharks and bat stingrays in San Francisco Estuary. The State of California Department of Fish and Game, 37(3), 315-330.

Herald, Earl S. (1953). The 1952 shark derbies at Elkhorn Slough, Monterey Bay, and at Coyote Point, San Francisco Estuary. The State of California Department of Fish and Game, 39(2), 237-244.

Hight, Barbara V., Lowe, \& Christopher G. (2007). Elevated body temperatures of adult female leopard sharks, Triakis semifasciata, while aggregating in shallow nearshore embayments: Evidence for behavioral thermoregulation? Experimental Marine Biology and Ecology, 352, 114-128.

Hobbs, J., Cook, J., \& Crain, P. (2015). Tidal marsh restoration benefits leopard sharks (Triakis semifasciata) in South Bay salt pond restoration project ponds. Resource Legacy Fund: Grant No. 2009-0080, 1-32.

Hopkins, Todd E., Cech, \& Joseph J. (2003). The influence of environmental variables on the distribution and abundance of three elasmobranchs in Tomales Bay, California. Environmental Biology of Fishes, 66, 279-291.

Jung, S., Shin-Ichi, K., Song J., \& Oh, M. (2007). Miamiensis avidus (Ciliophora: Scuticociliatida) causes systemic infection of olive flounder Paralichthys olivaceus and is a senior synonym of Philasterides dicentrarchi. Diseases of Aquatic Organisms, 73, 227-234.

Kao, Jon S. (2000). Diet, daily ration and gastric evacuation of the leopard shark (Triakis semifasciata) (master's thesis). California State University, Hayward.

Klosterhaus, S., Yee D., Sedlak, M., Wong, A., \& Sutton R. (2013). Contaminants of emerging concern in San Francisco Bay: A summary of occurrence data and identification of data gaps. Oakland, CA: San Francisco Estuary Institute. Retrieved 
from https://www.sfei.org/documents/contaminants-emerging-concern-san-franciscobay-summary-occurrence-data-and-identification.

Kusher, D. I., Smith, S. E., Cailliet G. M., \& Gregor, M. (1992). Validated age and growth of the leopard shark, Triakis semifasciata, with comments on reproduction. Environmental Biology of Fishes, 35, 187-203.

Lewallen, Eric A., Anderson, \& Todd W. (2007). Genetic structure of leopard sharks (Triakis semifasciata) populations in California waters. Marine Biology, 152, 599609.

Lund, Richard. (1990). Chondrichthyan life history styles as revealed by the 320 million years old Mississippian of Montana. Environmental Biology of Fishes, 27(1), 1-19.

Marine Science Institute. (2019). Retrieved from https://www.sfbaymsi.org/.

Mejia, F., Saiki, Michael K., Takekawa, \& John Y. (2008). Relation between species assemblages of fishes and water quality in salt ponds and sloughs in south San Francisco Estuary. The Southwestern Naturalist, 53(3), 335-345.

Miklos, P., Katzman, Shana M., Cech, \& Joseph J. Jr. (2003). Effect of temperature on oxygen consumption of the leopard shark, Triakis semifasciata. Environmental Biology of Fishes, 66, 15-18.

Miller, D. J. \& Lea, R. N. (1972). Guide to the coastal marine fishes of California (No. 157). California: Department of Fish and Game.

Mooi, R., Smith, V. G., Burke, M. G., Gosliner, T. M., Piotrowski, C. N., \& Ritger, R. K. (2007). Animals of San Francisco Bay: A field guide to common benthic species. San Francisco, CA: California Academy of Sciences. Retrieved from https://www.academia.edu/17526703/Animals_of_San_Francisco_Bay_a_field_guide _to_its_common_benthic_species.

Myers, R. A., Baum, J. K., Shepherd, T. D., Powers, S. P., \& Peterson, C. H. (2007). Cascading effects of the loss of apex predatory sharks from a coastal ocean. Science, 315, 1846-1850.

National Weather Service Forecast Office. (n.d.). San Francisco Bay Area/Monterey. Retrieved from https://w2.weather.gov/climate/xmacis.php?wfo=mtr.

Navia, A. F., Cortes, E., Jordan F., Cruz-Escalona, V. H., Mejia-Falla, P. A., \& Ali, M. (2012). Changes to marine trophic networks caused by fishing. InTech, 417-452. 
Nosal, A. P., Cartamil, D. C., Long, J. W., Luhrmann, M., Wegner, N. C., \& Graham, J. B. (2013). Demography and movement patterns of leopard sharks (Triakis semifasciata) aggregating near the head of a submarine canyon along the open coast of southern California, USA. Environmental Biology of Fishes, 96(7), 865878.

Paddison, J. (2005). 1848-1865: Gold rush, statehood, and the western movement. California: Regents of the University of California. Retrieved from https://calisphere.org/exhibitions/essay/4/gold-rush/.

Rabalais, N. N., Turner, E. R., Diaz, R. J., \& Justic D. (2009). Global change and eutrophication of coastal waters. ICES Journal of Marine Science, 66, 15281537.

Retallack, H., Okihiro, M. S., Britton, E., Sommeran, S. V., \& DeRisi, J. L. (2018). Metagenomic next-generation sequencing reveals Miamiensis avidus (Ciliophora: Scuticociliatida) in the 2017 epizootic of leopard sharks (Triakis semifasciata) in San Francisco Bay, California, USA. Journal of Wildlife Disease, 55(2). https://doi.org/10.7589/2018-04-097.

Russo, R. A. (1975). Observations on the food habits of leopard sharks (Triakis semifasciata) and brown smoothhounds (Mustelus henlei). California Fish and Game, 61(2), 95-103.

Russo, R. A. (2015). Observations of predation and loss among leopard sharks and brown smoothhounds in San Francisco Estuary, California. California Fish and Game, 101(2), 149-157.

Russo, R. A. (2019). Primary and secondary nursery areas for leopard and brown smoothhound sharks in San Francisco Bay, California. California Fish and Game, 105(1), 21-30.

Russo, R. A. \& Herald, E. S. (1968). 1967 shark kill in San Francisco Estuary. California Fish and Game, 54(3), 215-216.

Schraga, T. S., Nejad, E. S., Martin, C.A., \& Cloern, J. E. (2018). USGS measurements of water quality in San Francisco Bay (CA), beginning in 2016 (ver. 2.0, June 2018): U.S. Geological Survey data release. https://doi.org/10.5066/F7D21WGF.

Self, D. (2010). Sharks of San Francisco Bay. San Francisco Bay keeper. Retrieved from https://baykeeper.org/news/column/sharks-san-francisco-bay.

Simons, E. (2017a). Hunt for San Francisco Bay shark killer zeroes in on a suspect. 
Bay Nature. Retrieved from https://baynature.org/article/hunt-bay-shark-killernarrows-suspect/.

Simons, E. (2017b). Mysterious brain-eating shark killer identified, though questions remain. National Geographic. Retrieved from https://www.nationalgeographic.com/news/2017/10/brain-eating-disease-kills-sharksrays-san-francisco-bay-protozoan/.

Smith, S. E. (2001). Leopard Shark. California's living marine resources: A status report. California Department of Fish and Wildlife, 252-254. Retrieved from https://nrm.dfg.ca.gov/FileHandler.ashx?DocumentID=34265\&inline.

Smith, S. E. \& Horeczko, M. (2008). Leopard Shark. Status of the Fisheries Report, 14.1-14.7.

Smith, S. E. \& Abramson, N. J. (1990). Leopard shark Triakis semifasciata distribution, mortality rate, yield, and stock replenishment estimates based on a tagging study in San Francisco Estuary. Fish Bulletin, 88, 371-381.

Stevens, J. D., Bonfil, R., Dulvy, N. K. \& Walker, P. A. (2000). The effects of fishing on sharks, rays, and chimaeras (chondrichthyans), and the implications for marine ecosystems. ICES Journal of Marine Science, 57, 476-494.

Stewart, R. A., Luoma, S. N., Schlekat, C. E., Doblin, M. A. \& Hieb, K. A. (2004). Food web pathway determines how selenium affects aquatic acosystems: A San Francisco Estuary case study. Environment Science Technology, $38,4519-4526$.

Talent, L. G. (1976). Food habits of the leopard sharks, Triakis semifasciata, in Elkhorn Slough, Monterey Bay, California. California Fish and Game, 62 (4), 286-298.

Talent, L. G. (1985). The occurrence, seasonal distribution, and reproductive condition of elasmobranch fishes in Elkhorn Slough, California. California Fish and Game 71(4), 210-219.

Thompson, B., Adelsbach, T., Brown, C., Hunt, J., Kuwabara, J., Neale, J., Ohlendorf, H., Schwarzbach, S., Spies, R., \& Taberski, K. (2007). Biological effects of anthropogenic contaminants in the San Francisco Estuary. Environmental Research, $105,156-174$.

United States Geological Survey (2018). California water science center. United States Department of the Interior. Retrieved from https://ca.water.usgs.gov/california-drought/california-drought-comparisons.html. 
Webber, J. D. \& Cech, J. Jr. (1998). Nondestructive diet analysis of the leopard shark from two sites in Tomales Bay, California. California Fish and Game, 84(1): 1824.

Wilga, C. D., Motta, P. J., \& Sanford, C. P. (2007). Evolution and ecology of feeding in elasmobranchs. Integrative and Comparative Biology, 47(1), 55-69.

Woo, P. T. K. \& Buchmann, K. (2012). Fish Parasites: Pathology and Protection. Cambridge, MA: CABI International. 
Appendix: Kruskal- Wallis $\mathbf{H}$ permutations for analysis of interannual variation in

CPUE during the months of April to August from 1998 to 2017.

\begin{tabular}{|c|c|c|c|c|c|c|c|c|c|c|c|c|c|c|c|c|c|c|}
\hline ஜ̊ & ริ & ర్లి & $\overline{\bar{\delta}}$ & 尺్̊ㅇ & శి & ষ্ঠి & $\mid \begin{array}{l}n \\
\delta \\
\delta\end{array}$ & 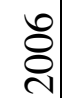 & ్ㅗ & $\begin{array}{c}\infty \\
\stackrel{\infty}{8} \\
\stackrel{\text { }}{ }\end{array}$ & శి & 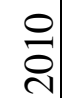 & $\overrightarrow{\bar{\Xi}}$ & స్ & $\frac{m}{8}$ & $\frac{ \pm}{8}$ & $\frac{n}{8}$ & $\frac{0}{8}$ \\
\hline Әे & శి & శి & & 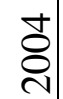 & 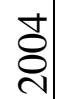 & $\mid \begin{array}{l}n \\
8 \\
8\end{array}$ & $\mid \begin{array}{l}0 \\
\text { ర్ల } \\
\text { | }\end{array}$ & હ్రి & $\mid \begin{array}{l}\infty \\
8 \\
8 \\
\text { ర }\end{array}$ & 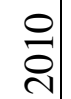 & $\bar{\Xi}$ & 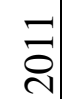 & 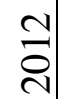 & $\frac{m}{\stackrel{్}{్}}$ & 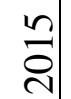 & స్తి & స్తి & $\bar{\nabla}$ \\
\hline ఫ્ઠి & 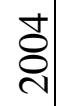 & 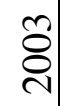 & & 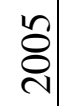 & 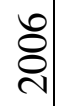 & ఠ్రి & $\begin{array}{l}0 \\
8 \\
8\end{array}$ & $\stackrel{\circ}{\stackrel{ }{\circ}}$ & $\begin{array}{l}\vec{\lambda} \\
\overline{\mathrm{N}}\end{array}$ & $\begin{array}{l}\overrightarrow{\mathrm{n}} \\
\mathrm{i}\end{array}$ & $\frac{m}{\bar{\delta}}$ & $\stackrel{m}{\stackrel{n}{N}}$ & $\stackrel{m}{\bar{\delta}}$ & $\underset{⿱ 亠}{\stackrel{\nabla}{d}}$ & 공 & & & \\
\hline 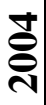 & 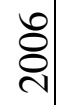 & ஜి & & $\begin{array}{l}\text { ○ి } \\
\text { రి }\end{array}$ & స్తి & 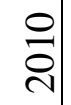 & $\begin{array}{l}\infty \\
\stackrel{\infty}{8} \\
\stackrel{్}{2}\end{array}$ & $\overrightarrow{\bar{D}}$ & $\frac{m}{\mathrm{~N}}$ & $\stackrel{m}{\stackrel{n}{\sigma}}$ & $\stackrel{\searrow}{\stackrel{\nabla}{\ominus}}$ & $\underset{⿱ 亠}{\stackrel{D}{\delta}}$ & $\stackrel{ \pm}{\stackrel{\nabla}{d}}$ & $\frac{n}{8}$ & & & & \\
\hline 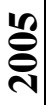 & હે & $\overrightarrow{\mathrm{D}}$ & & 홍 & $\begin{array}{l}\infty \\
\stackrel{\infty}{8} \\
\stackrel{\text { }}{2}\end{array}$ & 공 & ठి & $\stackrel{m}{\stackrel{\sim}{)}}$ & $\stackrel{ \pm}{\Xi}$ & 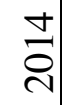 & $\stackrel{n}{0}$ & $\stackrel{n}{8}$ & $\stackrel{n}{8}$ & $\stackrel{0}{0}$ & & & & \\
\hline ஓ્ఠ్ & 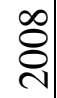 & $\stackrel{m}{\stackrel{2}{0}}$ & & $\begin{array}{l}\infty \\
\stackrel{\infty}{8} \\
\stackrel{\text { }}{2}\end{array}$ & 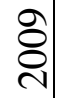 & n) & 웡 & $\underset{\circlearrowright}{\stackrel{\Xi}{~}}$ & $\frac{n}{8}$ & $\stackrel{n}{\stackrel{\sim}{\Omega}}$ & 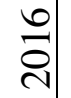 & $\begin{array}{l}0 \\
\stackrel{0}{0} \\
\end{array}$ & 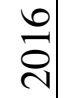 & & & & & \\
\hline હ્ণิ & ஓి & 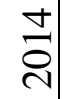 & & 용 & 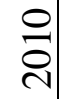 & 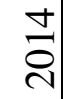 & $\overline{\mathrm{d}}$ & $\frac{n}{8}$ & $\begin{array}{l}0 \\
0 \\
0\end{array} \mid$ & 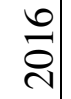 & & & $\stackrel{\bar{D}}{\mathrm{D}}$ & & & & & \\
\hline$\infty$ & 0 & $n$ & & 0 & $=$ & $n$ & $N$ & 6 & & & & & & & & & & \\
\hline ల్ల & $\overline{\mathrm{s}}$ & 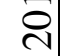 & & 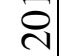 & $\stackrel{\mathrm{N}}{\mathrm{N}}$ & లి & $\overline{\mathrm{\Omega}}$ & $\stackrel{\mathrm{N}}{\mathrm{s}}$ & & & & & & & & & & \\
\hline 0 & - & 0 & & -1 & $N$ & 6 & in & & & & & & & & & & & \\
\hline ల్ల & $\overline{\mathbf{\Omega}}$ & $\overline{\mathrm{N}}$ & & $\widehat{\overbrace{}}$ & లి & $\bar{\Upsilon}$ & $\bar{ల}$ & & & & & & & & & & & \\
\hline 0 & $N$ & & & $N$ & $m$ & & $r$ & & & & & & & & & & & \\
\hline త్లి & $\overline{\mathbf{v}}$ & & & $\widehat{\overbrace{}}$ & లి & & సి & & & & & & & & & & & \\
\hline & $m$ & & & $m$ & 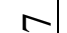 & & & & & & & & & & & & & \\
\hline & $\bar{\delta}$ & & & & $\overline{\mathrm{c}}$ & & & & & & & & & & & & & \\
\hline N & $r$ & & & N & & & & & & & & & & & & & & \\
\hline & $\bar{\nabla}$ & & & $\overline{\mathrm{d}}$ & & & & & & & & & & & & & & \\
\hline
\end{tabular}

